\title{
Three Pillars of Novel Nonthermal Food Technologies: Food Safety, Quality, and Environment
}

\author{
Anet Režek Jambrak (D), ${ }^{1}$ Tomislava Vukušić $\left(\mathbb{D},{ }^{1}\right.$ Francesco Donsi, ${ }^{2}$ Larysa Paniwnyk, ${ }^{3}$ \\ and Ilija Djekic (iD ${ }^{4}$ \\ ${ }^{1}$ Department of Food Engineering, Faculty of Food Technology and Biotechnology, University of Zagreb, Zagreb, Croatia \\ ${ }^{2}$ University of Salerno, Fisciano, Italy \\ ${ }^{3}$ Coventry University, Coventry, UK \\ ${ }^{4}$ Department of Food Safety and Quality Management, Faculty of Agriculture, University of Belgrade, Belgrade, Serbia
}

Correspondence should be addressed to Ilija Djekic; idjekic@agrif.bg.ac.rs

Received 28 March 2018; Revised 28 May 2018; Accepted 4 June 2018; Published 8 July 2018

Academic Editor: Jordi Rovira

Copyright ( 92018 Anet Režek Jambrak et al. This is an open access article distributed under the Creative Commons Attribution License, which permits unrestricted use, distribution, and reproduction in any medium, provided the original work is properly cited.

\begin{abstract}
This review gives an overview of the impact of novel nonthermal food technologies on food safety, on quality, and on the environment. It confirms that research in this field is mainly focused on analyzing microbial and/or chemical aspects of food safety. However, recent research shows that in spite of various food safety benefits, some negative (quality oriented) features occur. Finally, this paper shows the necessity of analyzing the environmental dimension of using these technologies.
\end{abstract}

\section{Introduction}

Nonthermal technologies are used in interdisciplinary sciences, in biotechnology, and in many other research and applied areas. In food processing, they are used mainly for preservation in treating of food and wastewaters. Consumer demands for minimally processed foods in addition to the negative effect of heat on nutritional properties of foods are making nonthermal processing popular in the food industry. The main task of nonthermal processing is to assure food safety [1], and research effort is focused on microbial inactivation, food safety, and preservation while retaining the quality of obtained products. This advantage gives nonthermal processing the potential to replace classical thermal processing. Besides the food safety and quality dimensions, these processing technologies have the possibility to shorten treatment time, lower energy consumption, and lower carbon footprint [2].

Nonthermal technologies have different types of action, depending on the source of energy transfer. They are used in inactivation of microorganisms in radical formation (plasma, ultrasound, ozonation, UV light, etc.); mechanical action through hydrodynamic effects, shock waves (ultrasound and plasma), electric and magnetic fields (pulsed electric fields, cold plasma, radiofrequency and oscillating magnetic fields, electrohydrodynamic processing, and electron beam processing); or extremely high pressures that are causing rupturing and bursting of microorganisms [3-6]. These treatments may be used alone or in combination, within the so-called "hurdle" concept [7-9]. The most researched techniques with proven scientific results in the food industry are high-pressure processing (HPP), supercritical fluid extraction $\left(\mathrm{scCO}_{2}\right)$, and pulsed electric fields (PEFs).

There are many research projects dealing with microbial inactivation [10-12], enzyme inactivation [11, 13], and nutritional improvements [14-16] when using nonthermal technologies. All of these techniques have been successfully applied in assuring food safety [17-20]. However, besides assuring food safety, more attention is needed to maintain or improve food quality. Quality of food after nonthermal processing has shown both positive $[21,22]$ and negative [23-25] effects depending on the technique and processing 


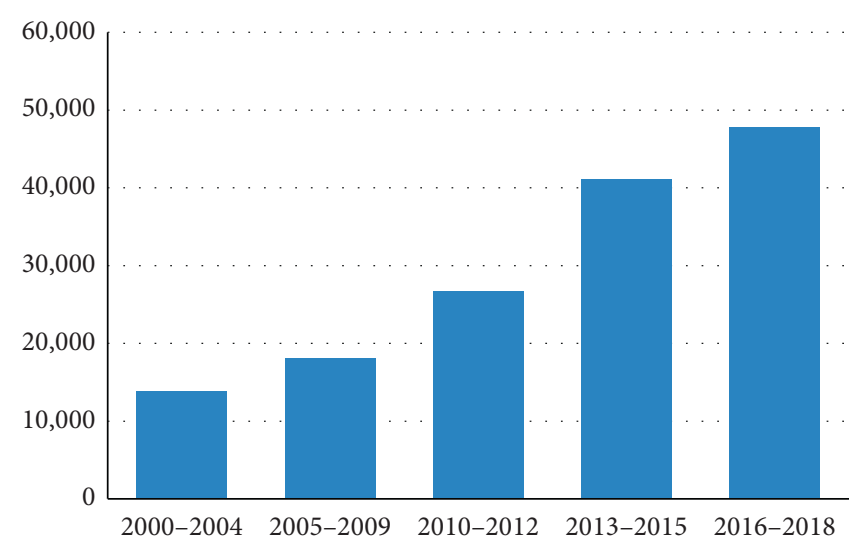

(a)

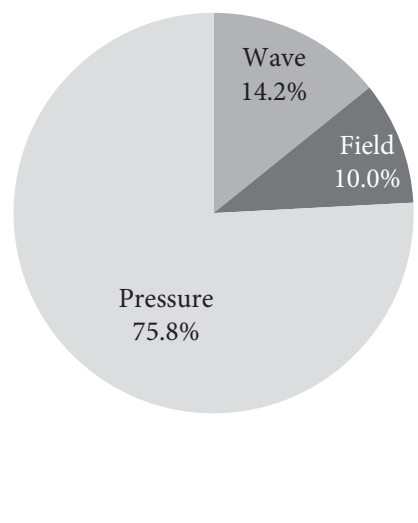

(b)

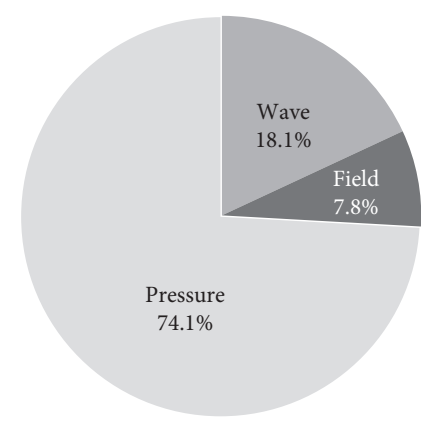

(c)

Figure 1: Presentation of publications related to the application of nonthermal technologies in the food industry: (a) number of publications; (b) share of publications; (c) share of patents. Wave: ultraviolet, ultrasound, and plasma; field: electric and magnetic fields' technologies; pressure: high-pressure processing/homogenization.

parameters. This raises the first challenge in succeeding inactivation of microorganisms while impairing quality and sensory parameters of treated samples and opens a research gap of unresearched areas like negative aspects of application of novel nonthermal processing on food quality, stability of food during shelf life after nonthermal processing, negative sensory properties of food treated by novel nonthermal techniques, life cycle assessment, and sustainability of nonthermal processing techniques. Advantages of novel nonthermal processing in terms of energy consumption can be considered as "green" techniques for "green" extraction. In order to gain better output products using nonthermal processing, it is important to overview processing in terms of safety, quality, and environmental aspects.

The objective of this review paper was to present the three main pillars related to the use of novel food technologies - food safety, quality, and environmental impacts on the one side stressing advantages and constraints and on the other side revealing future synergic research perspectives.

\section{Materials and Methods}

Online literature on the use of nonthermal technologies in the food industry is dispersed in a heterogeneous way in the form of scientific manuscripts, book chapters, conference proceedings as well as patents, legislation, and even company reports. According to our goal, we carried out a search in scientific literature spanning the research for the period 2000-2018. The authors mainly focused the attention on the international journals to assure a more scientific content mainly caused by a rigorous revision process. Therefore, the selection of scientific manuscripts was based on the journals impact factor, matching to the scope of the journal and preferring those indexed by international repositories such as the Scopus index and publishers (Elsevier, Springer, Wiley, Taylor and Francis, and EBSCO). This research identified relevant articles, both review and research papers, published in the domains of nonthermal technologies split into two subsections: specific nonthermal technologies (HPP, scCO2, PEF, etc.) and its application on the specific type of food (beverages, fruit, vegetables, etc.). There were no geographical restrictions applied.

This type of literature review identified that there are over 300,000 publications related to the application of nonthermal technology in the food industry. In this millennium, the number is increasing as presented in Figure 1(a) where the period before 2010 was divided into two fiveyear periods: 2000-2004 and 2005-2009. The period starting from 2010 was analysed in three-year periods. Although there are papers published in journals that are not strictly in the "food science and technology" scope, the top five journals that have at least 500 publications are Food Chemistry, LWT Food Science and Technology, Journal of Food Engineering, Innovative Food Science and Emerging Technologies, and Food Research International. The journal covering the environmental impact of these technologies is published in the Journal of Cleaner Production and Bioresource Technology. Depending on the type of technology, the share of publications and patents was analysed and is presented in Figures 1(b) and 1(c). It is important to note that high-pressure processing and homogenization are the most analysed technologies in around $75 \%$ of all research/review publications. The same applies to publication of patents.

Deeper analysis of patents reveals that the majority of patents were published in journals up to 2010 and covered patents of new nonthermal technologies, food substitution with novel food derived from new technologies, and aspects of food preservation using these technologies. Majority of patents came from the developed countries (EU, USA, China, Japan, Australia, etc.), and no other patterns were observed.

A literature review revealed that these technologies were evaluated separately either from a food technology/food safety perspective or from an environmental perspective. Combination of two types of criteria-environmental and quality/food safety-has not been a focus of research, and 
this has been identified as a research gap by the authors of this paper.

\section{Safety of Food Processed with Nonthermal Technologies}

Nonthermally processed food presents some kind of a risk due to incomplete preservation of food. At the beginning of an extensive research and application of nonthermal food technologies, the US Food and Drug Administration (FDA) requested the Institute of Food Technologists (IFT) to give a report on the effectiveness of microbial inactivation of alternative food-processing technologies. Back in 2000, the IFT reported general guidance for future research on novel techniques based on microbiological demands like the evaluation of the adequate linear first-order survivor curve model and launching experimental protocol, identifying inactivation action/mechanism(s) among alternative technologies, and determining the synergism or antagonism of one alternative processes [26]. The IFT also emphasized the importance to determine potential formation of indigestible and toxic by-products of processing as well to develop methods for measuring and monitoring physical-chemical changes during treatments [26].

As a result, from the year 2004, the definition of pasteurization changed and now, according to the National Advisory Committee on Microbiological Criteria for Foods (NACMCF) of the USDA, includes any process, treatment, or combination, which is applied to food to assure microbial safety [27]. In order to evaluate alternative pasteurization methods, there are several steps to pay attention on, like the properties and composition of the treated food product, microbial effects, and commercial, economic, and environmental aspects [28]. Each of these technologies has specific critical process parameters that must be monitored and controlled (critical control points).

The Novel Food Regulation by the EU lacks a joint classification of new technologies across all member states which slows down their widespread commercialization in Europe. In order to proceed with the technology readiness levels of novel food technologies, one of the necessary prerequisites is to validate them in relevant environment [29]. Novel food technologies may be used for different purposes in the food industry [30], such as (1) preservation/ decontamination and shelf life extension, (2) food modification (i.e., gelatinization), (3) stress induction (i.e., increase in biosynthetic activities), (4) mass transfer modification (i.e., extraction), and so on.

In parallel with developing nonthermal technologies, it is of vital importance that equipment is hygienically designed [31]. Hygienic design is defined as "design and engineering of equipment and premises assuring that food is safe and suitable for human consumption" [32]. It is not widely understood, and there is still little awareness of possible consequences of equipment that is not hygienically designed [33]. Public health and economic aspects of microbial contamination in foods may cause financial and public concerns, particularly if these result in product recalls. The hygienic design of equipment plays an important role not only in controlling the microbiological safety and quality of the products made but also in prevention of residues of chemicals used for cleaning and disinfection. Also, the hygienic design should prevent food from being contaminated with other contaminants. This becomes more important with novel food-processing technologies where new designs may result in new (re)contamination pathways, while minimized food processing may not achieve heatstandard inactivation [9].

Legislation covering the hygienic design of foodprocessing equipment is vague [34]. In the EU, some legislation mentions the importance of the hygienic design such as the regulation of hygiene of foodstuffs [35]. On the contrary, there are a number of different types of standards related to the hygienic design with different approaches in highlighting similar hygiene issues [33]. Most used standards that outline requirements related to the hygienic design are industry-tailored guidelines or sanitary standards [36-39].

3.1. Microbial Food Safety. All aspects of microbial food safety need to be monitored, and this includes assuring FDA regulative for $5 \log$ reduction using preservation processes. High-pressure processing (HPP) and pulsed electric fields (PEFs) have been greatly researched and proved to be successful in assuring food safety, and by that, they were successfully commercialized $[4,40,41]$ dealing with nonthermal inactivation of microorganisms. PEF provides minimal changes in food attributes while assuring optimum safety. Pulsed light is used in decontamination of various (transparent) liquids. However, limitation of this technology leads to undesirable results, such as decomposition of nutrients and changes in sensory quality. Food safety is one of the important components that force the development of novel technologies to reduce, control, or eliminate foodborne pathogens from food products and contact surfaces. State of the art of assuring and demonstrating $5 \log$ reduction was described in terms of applying optimized nonthermal treatment $[1,20,42]$. Nonthermal techniques can be combined $[10,13,43-46]$ or be used with antimicrobial agents [47-49] or in combination with mild heating $[1,22,50]$. It is necessary to follow critical control processes of nonthermal processing [51-53] in order to have no recovery or revitalization of microorganisms after processing $[54,55]$. There are laboratories in the United States that validate food process for all nonthermal techniques, and processing needs to be evaluated and overviewed for microbial stability, toxicology, interactions between the product and packaging, chemistry, and so on. Foods derived from these technologies are also subject to this kind of validation.

High pressures result in extreme mixing and highintensity shear forces moving throughout the medium. This release can result in examples of aggregate disruption, polymer chain fractures, and chain length degradation causing permanent changes in molecules [56]. This mechanism works particularly well at low frequencies such as 20 and $40 \mathrm{kHz}$. Although ultrasound has shown some 
benefits to processing of foods, for example, in extraction, crystallization, and microbial inactivation, there are also some concerns as expressed by Pingret et al. [25] who presented a review on the possible degradative effects of sonication on food with high lipid contents and indicated the possible degradation of some compounds and changes to physiochemical qualities of some food products.

The extent of microbial inactivation by HPP in foods depends on multiple factors related to the processing conditions and the food matrix. Additionally, it was broadly observed that different microorganisms express a wide range of sensitivity to HPP $[57,58]$.

In particular, prokaryotic cells are observed to be more pressure resistant than eukaryotes [57], yeasts and moulds are relatively more HPP sensitive than bacteria, and Grampositive bacteria are more resistant to pressure than Gramnegative bacteria, likely because the higher complexity of the cell or of the cell membrane might increase HPP susceptibility [59]. Additionally, cocci are more resistant than rodshaped bacteria [59].

However, the most resistant species are the endospores, which are capable of withstanding pressures $>1,000 \mathrm{MPa}$ [59]. HPP is reported to induce the germination of bacterial spores, at an extent depending on the food matrix and the microorganism $[59,60]$.

In general, the efficiency of high-pressure homogenization $(\mathrm{HPH})$ for microbial inactivation depends on the properties of the process fluid (viscosity, temperature, suspended solids, or fats), the specific resistance of the microbial strains, and the operating conditions, such as the operating pressure, the number of $\mathrm{HPH}$ passes, the operating temperature, and the homogenizing valve geometry [61]. The pressure limit separating HPH (high-pressure homogenization) from UHPH (ultrahigh-pressure homogenization) is not clearly defined, whereas pressures above $200 \mathrm{MPa}$ are often named UHPH $[62,63]$.

The inactivation kinetics for most microorganisms appear to be first order with respect to the applied pressure, in the range of $\mathrm{HPH}$ and $\mathrm{UHPH}$ pressure levels (100-350 MPa) [64]. In contrast, for repeated $\mathrm{HPH}$ passes, an asymptotic behavior is generally observed, which can be attributed to the natural distribution of individual cell resistance to pressure [65]. Moreover, the homogenizing valve geometry also appears to be determining factors for microbial inactivation. In fact, the microbial inactivation is a direct consequence of the physical cell disruption due to the fluidmechanical stresses generated in the valve, such as shear and elongational stresses, turbulence, cavitation, and impact on the valve surfaces, which depend on the specific valve design $[66,67]$.

Due to the temperature rise in the homogenization valve and due to the frictional heating associated with the pressure energy dissipation, the thermal inactivation of the microorganisms is likely to occur during $\mathrm{HPH}$ treatments, if the inlet and outlet temperatures are not carefully controlled.

If a purely nonthermal treatment is desired, to preserve the thermosensitive food components, the inlet temperature should be adjusted as a function of the operating pressure, taking into account the inherent heating of the system (generally comprised between 0.15 and $0.22^{\circ} \mathrm{C} / \mathrm{MPa}$ ) [68]. Moreover, also a heat exchanger should be placed immediately downstream of the homogenizing valve, which is desirable to minimize thermal damage to the product.

Both $\mathrm{HPH}$ and UHPH treatments primarily kill the vegetative bacteria, through the mechanical destruction of the cell integrity $[61,67]$. Gram-positive bacteria are reported to be more resistant than Gram-negative bacteria, which have thinner cell walls, formed by 1-5 layers of peptidoglycan chains, in comparison with the 40 layers of peptidoglycan chains of the Gram-positive bacteria $[69,70]$.

Yeasts and fungi exhibit an HPH resistance, which is intermediate between Gram-negative and Gram-positive bacteria, because of their wall structure, which is thicker than that in Gram-positive bacteria, but more complex than that in Gram-positive bacteria due to the larger size and a different cell wall structure, with glucans, mannans, and proteins as basic structural components [71].

There are different actions of nonthermal processing, but in some use of one technology per se is not enough to assure inactivation of microorganisms in a significant way. Efficiency in inactivation of microorganisms by those treatments differs depending on treatment parameters like treatment time, power, strength, dosage, frequency, and so on. On the other hand, by working at lower temperatures, there are possibilities that applied treatment is not enough in prolonging the shelf life of the product and there are significant hazards like revitalization and recovery of microorganisms (sublethal injuries, stress, viable but nonculturable state, etc.). When nonthermal treatments achieve food safety, there is possible deterioration of food quality. One example is treated wine which was treated by ultrasound. Ultrasound caused the formation of negative oxidative smell and the formation of aromas which are described by panellists as burns or smoke [72]. It is explained by the formation of oxidized aroma (acetaldehyde) in young red wines, that is, the reaction of wine polyphenols (initiated by the ultrasound treatment) to form peroxide which oxidizes ethanol to acetaldehyde. This is often observed in high oxidative techniques (plasma, ultrasound, etc.). Through formation of free radical and high reactive oxygen or nitrogen species, the nonthermal processing can be efficiently introduced in wastewater treatments and recovery of agro and food waste.

Another area of safety concerns within food processing is sterilization and reduction of contamination by bacteria and other microbes. Ultrasound has been shown to be very effective in treating the rate of bacterial growth and increasing the kill rate of microbes at a range of frequencies, the most effective being $850 \mathrm{kHz}$ due to the short life span of the cavities at this frequency. It is thought to affect microbial inactivation via the weakening or disruption of bacterial cells through a number of different processes which include mechanical and chemical effects. Mechanical effects are induced by sonication at lower frequencies of $20 \mathrm{kHz}$, as a result of increased pressure gradients formed during the collapse of cavitation bubbles within or near the bacteria, which result in enhanced shear forces, microstreaming, and high levels of mixing resulting in disruption of the bacteria. Evidence continues to grow for the use of ultrasound in the 


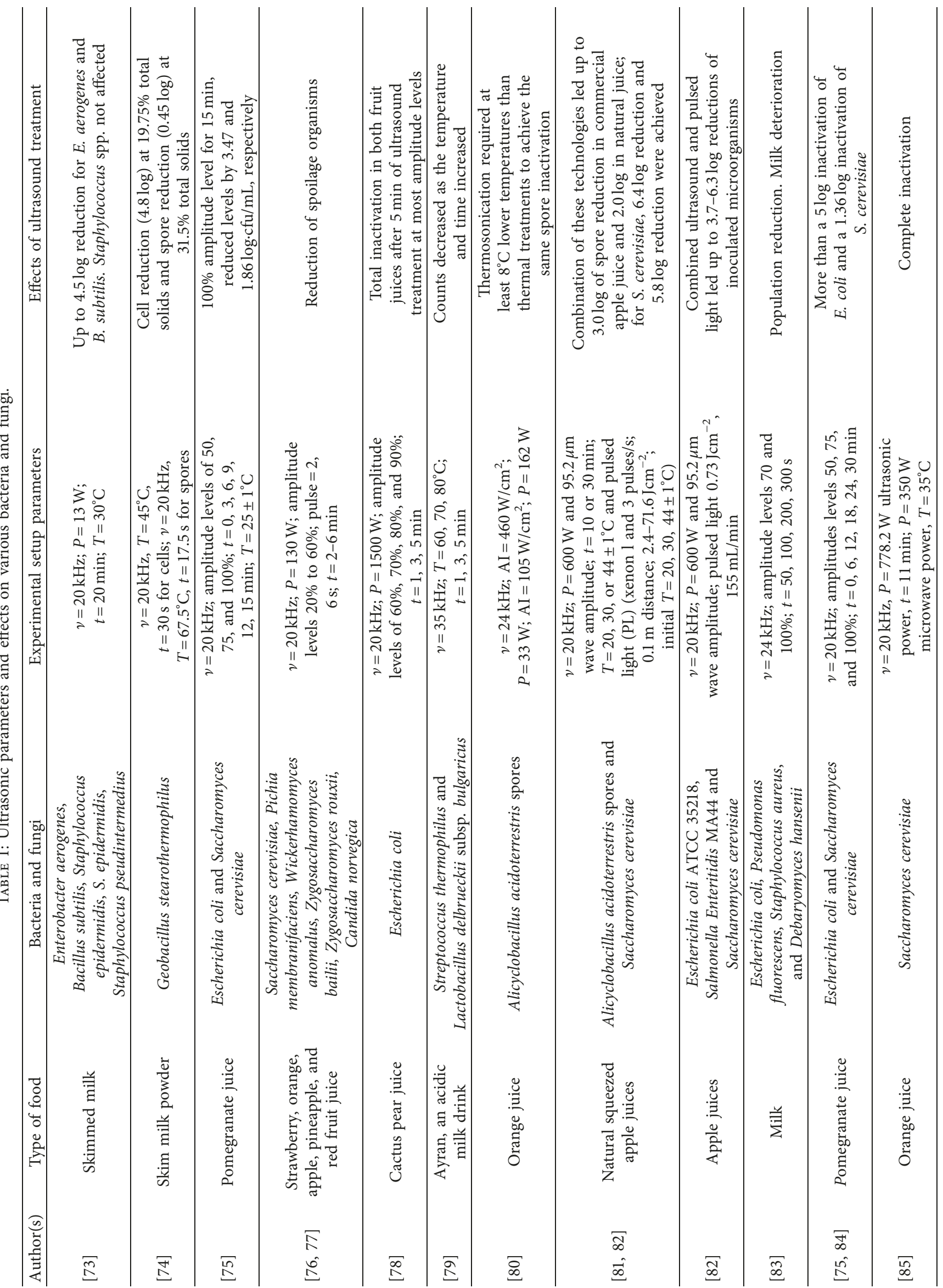




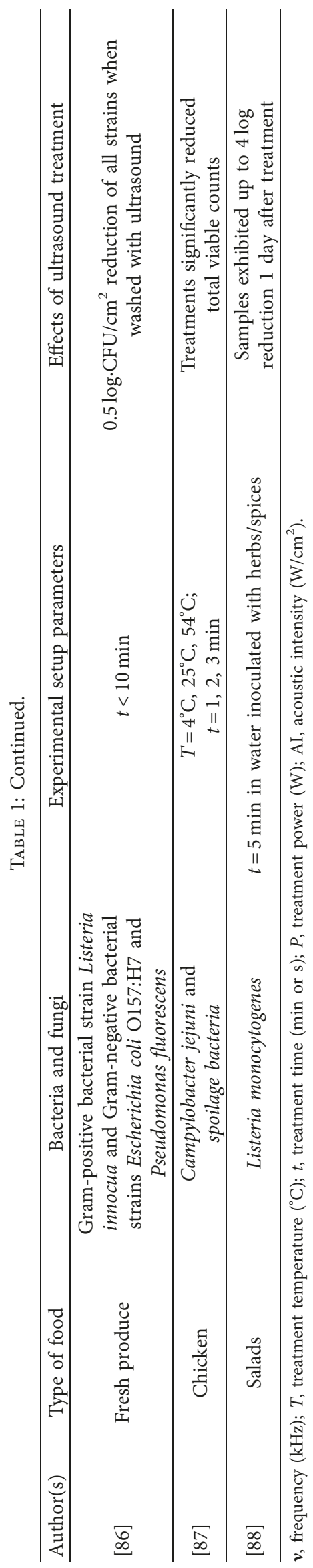


deactivation and sterilization of many different bacterial strains. This can be achieved within short treatment times with higher frequencies of sonication, thus resulting in minimal disruption to the food material itself. An overview of ultrasound effects on microbial safety is presented in Table 1.

Liu et al. [89] investigated the inactivation of Saccharomyces cerevisiae under varying conditions such as bacterial load concentration, $\mathrm{pH}$, and treatment temperature and determined that ultrasound had the most significant role in the inactivation of the bacteria. Kang et al. [90] examined the effects of ultrasound on the number of Escherichia coli O157:H7 and vegetative cells of Bacillus cereus in brining and beef during the curing processing. After $30 \mathrm{~min}$ of treatment, E. coli appeared to be more affected by sonication than the $B$ cereus. This was thought to be due to the formation of hydrogen peroxide acting as a sterilization agent as a result of recombination reactions of $\mathrm{OH}$ radicals during the sonication process. Sienkiewicz et al. [91] examined the growth of the strain of Salmonella enterica subsp. typhimurium during sonication. Total inactivation of Salmonella spp. occurred with low bacterial populations after sonication at 20 and $40 \mathrm{kHz}$ for $30 \mathrm{~min}$ and with high bacterial population at $20 \mathrm{kHz}$ for $30 \mathrm{~min}$ with reductions observed after only $15 \mathrm{~min}$ of treatment. Bacterial inactivation, after sonication, lasted for up to $48 \mathrm{~h}$ in storage at $21^{\circ} \mathrm{C}$.

The levels of Campylobacter jejuni and spoilage organisms in raw chicken were examined by Kassem et al. [87] who employed sonication alone or in combination with different solutions containing either lactic acid, sodium decanoate, or trisodium phosphate at a range of temperatures and treatment times. While all the solutions exhibited some reduced bacteria levels as compared to the control, combination treatments fared far better with only sonication in conjunction with $3 \%$ sodium decanoate solution showing any significant improvements and much reduced total viable counts.

Khandpur and Gogate [48] investigated microbial growth in a range of fruit and vegetable juices via the application of sonication in the presence and absence of crude orange oil and compared these to thermal controls alongside other quality parameters such as $\mathrm{pH}$, acidity, Brix, and yeast content. The optimized ultrasound parameters for juice sterilization were ultrasound frequency and power of $20 \mathrm{kHz}$ and $100 \mathrm{~W}$ with a $15 \mathrm{~min}$ treatment time, and more than $5 \log$ reduction was achieved with lower microbial growth and improved quality characteristics as compared to the thermally processed juice.

3.2. Chemical Food Safety. Milne et al. [92] examined $\mathrm{OH}^{*}$ radical formation employing ultrasonic frequencies. Comeskey et al. [93] also employed a range of ultrasonic frequencies to determine levels of hydrogen peroxide formed in sonicated aqueous systems. Using a range of ultrasonic frequencies, they determined that the highest levels of hydrogen peroxide occurred at $850 \mathrm{kHz}$ with
380 and $512 \mathrm{kHz}$ also exhibiting some oxidative effects however not to the same extent.

Kang et al. [94] investigated treatment time versus ultrasonic power in an attempt to examine the oxidation of beef proteins. They determined that sonicating beef under varying treatment conditions greatly increased the amount of lipid oxidation compared to static brining. Protein oxidation was determined by examination of carbonyl levels and levels of disulphide cross-linking, which indicated a decrease in total sulfhydryl, as a result of free radicals contributing to protein oxidation. Continuing their work, Kang et al. [90, 95] sonicated beef at 150 and $300 \mathrm{~W}$ for 30 and $120 \mathrm{~min}$ and found that this increased the water holding capacity and tenderness of the beef as compared to salt brining. This was in this case attributed to induced oxidation of myosin causing polymerization of the muscle fibres, thus increasing the water holding capacity of the meat.

Sun et al. [96] examined the link between anthocyanin degradation and ultrasonically formed hydroxyl radicals. They discovered that the absorbance of the antioxidant cyanidin-3-glucosylrutinoside at 282 and $518 \mathrm{~nm}$ decreased significantly on increased sonication which was confirmed by 1,1-diphenyl-2-picrylhydrazyl and ferric-reducing antioxidant assays, thus indicating a negative effect on antioxidant levels as a direct result of extended sonication. Yao et al. [97] also observed a similar effect when examining the effect of sonication on antioxidant levels in blueberries and discovered that sonication significantly increases the degradation of cyanidin-3-glucoside as compared to thermal treatments.

The inactivation of horseradish peroxidase was investigated by Tsikrika et al. [98] who determined that sonication for $60 \mathrm{~min}$ using $20,378,583,862,995,1144$, and $1175 \mathrm{~Hz}$ ultrasound at power levels (acoustic energy) between 2.1 and $64 \mathrm{~W}$ was very effective at inactivating the enzymes with little effect observed at the $20 \mathrm{kHz}$ lower frequency. The fact that the greatest levels of inactivation were observed at 378 and $583 \mathrm{~nm}$ suggests that some radical effect may be the cause. There is much evidence presented to suggest that it is the higher frequencies of sonication, above $370 \mathrm{kHz}$ to $850 \mathrm{kHz}$, which result in high levels of oxidative radical formation. It is therefore suggested that, in order to avoid radical interference with food materials, lower frequencies for treatment should be employed with shorter sonication times to limit any oxidative effects.

Food allergies have posed a severe risk in the last decade. According to [99], allergic reactions are caused mainly due to "epitopes," a small linear stretch of amino acids or a specific three-dimensional structure which is a part of a much larger protein. During food processing (both conventional and novel), the epitopes that are present within the food matrix may be destroyed or new epitopes may be formed. Also, these technologies can result in producing conformational changes in the protein structure and formation of epitope centres, but also few of them can be used for the future development of the hypoallergenic foods by reduction or by mitigation of the reactivity on processing. Scientists are still trying to explain and understand the 
conformational changes in the protein which can affect the allergenicity.

\section{Quality of Food Processed with Nonthermal Technologies}

Stakeholders, such as legislators, retailers, and manufacturers, care about consumers' opinion regarding food processed with novel technologies [100]. Giving the possibility to evaluate and to taste, a novel product seems to influence consumer acceptance for new technologies. This is still largely an unexplored area, but it has been suggested that including consumers in the process of evaluation, that is, by pairing the new technology with a positive sensory experience of the product, can lead to the positive consumers' reaction [101].

High-pressure processing (HPP) might significantly impact the quality and functionality of food, affecting the color, flavor, and texture, with a relevant impact on sensory perception and consumer acceptance [61]. Generally, HPP, by slowing down some biological reactions, such as Maillard's reactions, contributes also indirectly to a better preservation of the quality attributes and nutritional value over their shelf life [102]. In addition, HPP is reported to have only a limited effect on the covalent bonds of lowmolecular-mass compounds, such as those responsible for color, flavor, and health-beneficial attributes. For example, HPP at low and moderate temperatures did not cause any significant alterations of the pigments, such as chlorophyll, carotenoids, and anthocyanins, responsible for the color of fruit juices [103]. The color compounds can, however, change during the storage of HPP-treated products more rapidly than in thermally treated ones, due to the incomplete inactivation of enzymes and microorganisms by high pressure [61].

Several studies clearly showed that the flavor of fruit juices is not affected by HPP because the structure of small molecular flavor compounds is only marginally affected by high pressure [104-107]. However, similar to pigments, the flavor of fruits and vegetables subjected to HPP might be indirectly altered, through enhancing or delaying of some enzymatic reactions, which might alter the balance of flavor composition $[105,108,109]$. HPP is also reported to affect the rheological behavior of the juices and their cloud stability, as both these parameters are controlled by the composition of the soluble pectins. Pectin breakdown or retention, induced by HPP also through enzymatic reactions, enables the control of the rheological behavior of the juice. For example, the residual activity of pectin methylesterase, not completely inactivated by HPP, caused a decrease in orange juice viscosity during its shelf life [109]. In contrast, the viscosity of tomato juice was observed to increase linearly with pressure, in the high pressure range (200-500 MPa), whereas at low pressures (100-200 MPa), a decrease in viscosity was observed because of enzymatic degradation of pectins [110].

One of the main quality indicators upon food processing is the preservation of the content of bioactive molecules, which might contribute to the health-beneficial properties of the food products. Remarkably, nonthermal technologies not only are reported to better preserve bioactives than thermal treatments but also in some cases can stimulate their release from the intact cells contained in the product, which translates in the increase of instrumentally detectable bioactive concentration and, often, of their bioaccessibility. In fact, HPP of vegetable cells at $250 \mathrm{MPa}$ for $10 \mathrm{~min}$ was reported to induce $99 \%$ of the pigment to be released [111].

Figure 2(a) summarizes the effect of HPP on different bioactive compounds, in comparison with the corresponding values in untreated products.

Vitamin A was reported to increase slightly in orange juice, treated between 100 and $400 \mathrm{MPa}$ for $1-5 \mathrm{~min}$ at temperatures between 30 and $60^{\circ} \mathrm{C}$ [112], and significantly in apple juice treated for $5 \mathrm{~min}$ at 400 and $500 \mathrm{MPa}$ and 25 and $45^{\circ} \mathrm{C}[61]$.

In contrast, different authors reported that vitamin $\mathrm{C}$ decreased upon high-pressure homogenization (HPH) and ultrahigh-pressure homogenization (UHPH) treatment, as observed in orange juice [112], in blueberry juice treated at HPP pressures between 200 and $600 \mathrm{MPa}$ and at temperatures of $42^{\circ} \mathrm{C}$ for 5-15 min [113], and in melon pieces treated for $10 \mathrm{~min}$ at HPP $600 \mathrm{MPa}$ and ambient temperature [114]. In the case of vitamin $\mathrm{E}$, a slight decrease was observed in rosehip puree, HPP treated at $200-600 \mathrm{MPa}$ and $20^{\circ} \mathrm{C}$ for 5 or $10 \mathrm{~min}$ [115], whereas a measurable increase was reported by the same authors for spinach leaves [115] and in sliced ham, HPP treated at $400-900 \mathrm{MPa}$ and $12^{\circ} \mathrm{C}$ for $10 \mathrm{~min}$ [116].

In the case of total carotenoids and of their main components, such as $\beta$-carotene, lutein, and zeaxanthin, it is generally reported that they are well preserved during HPP. In rosehip puree, similar to what reported for vitamin E, a decrease in total carotenoids, and in particular in lutein and zeaxanthin, was observed, while in spinach leaves, the total carotenoids were reported to increase [115].

In melon pieces treated by HPP, $\beta$-carotene was observed to increase, differently from what was observed for vitamin $C$ [114]. In orange juice treated between 100 and $400 \mathrm{MPa}$ for $1-5 \mathrm{~min}$ at temperatures between 30 and $60^{\circ} \mathrm{C}$, $\beta$-carotene, lutein, and zeaxanthin significantly increased [112]. Remarkably, in bee pollen paste treated at 200$400 \mathrm{MPa}$ and $20^{\circ} \mathrm{C}$ for $5-15 \mathrm{~min}$, a substantial increase in total carotenoids was observed [117].

The anthocyanins slightly decreased in blood orange juice treated at $400-600 \mathrm{MPa}$ and $20^{\circ} \mathrm{C}$ for $15 \mathrm{~min}$ [118], while significantly increased in must obtained from grapes treated at $400-550 \mathrm{MPa}$ and $20^{\circ} \mathrm{C}$ for $10 \mathrm{~min}$ [119].

$\mathrm{HPP}$ at $400-600 \mathrm{MPa}$ and $25-50^{\circ} \mathrm{C}$ for 5 or $10 \mathrm{~min}$ caused a decrease of the total polyphenols in pomegranate juice [106], whereas in blueberry juice [113] and in bee pollen paste [117], total polyphenols significantly increased. In the preservation of anthocyanins and polyphenols, a significant role is also played by the inactivation by HPP of the enzymes responsible for their degradation [120].

HPH and UHPH treatments are reported to better preserve the natural functional compounds of the juices, such as vitamins $\mathrm{C}$ and $\mathrm{A}$, flavonoids, and polyphenols, while reducing the microbial load to the desired value [121-123]. 


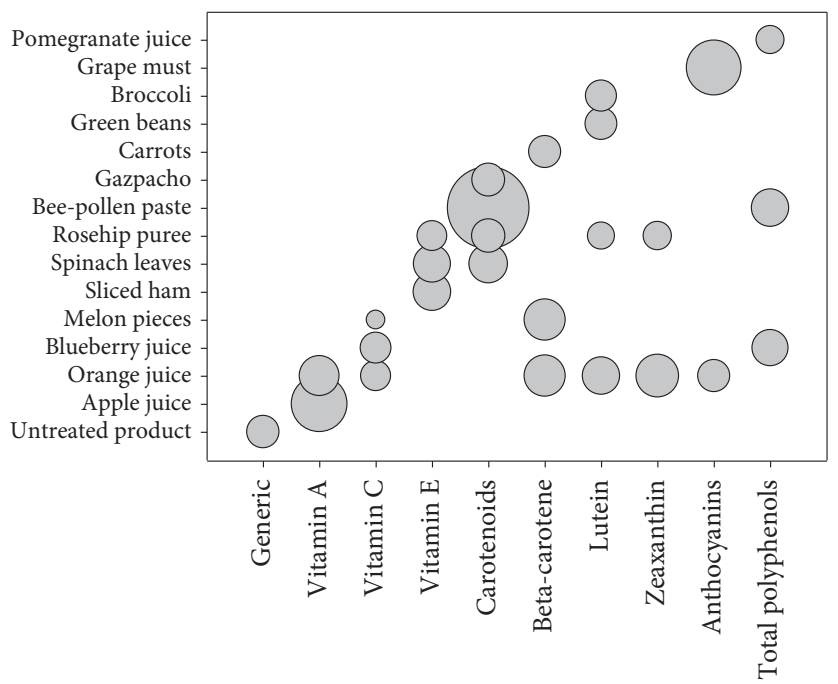

(a)

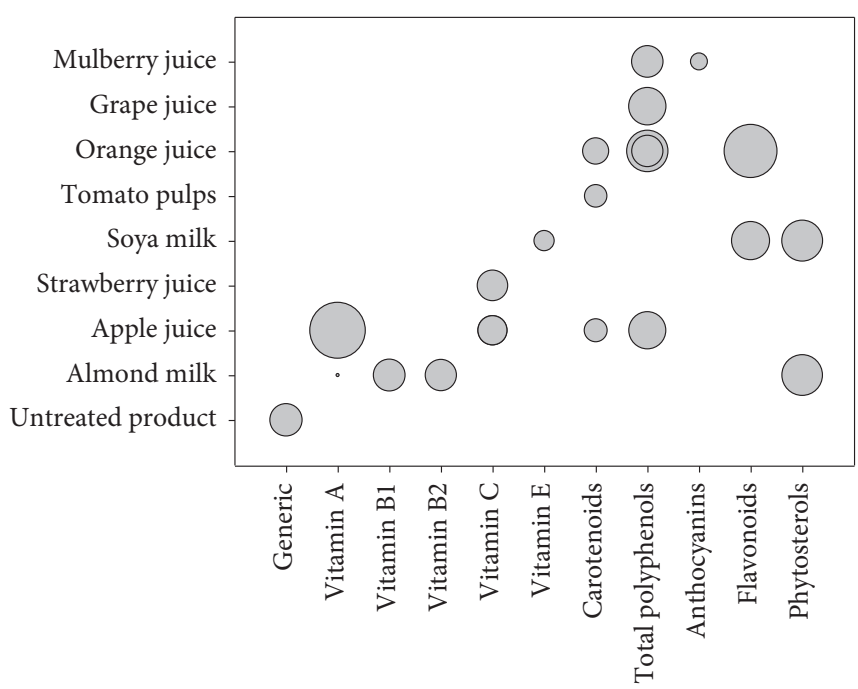

(b)

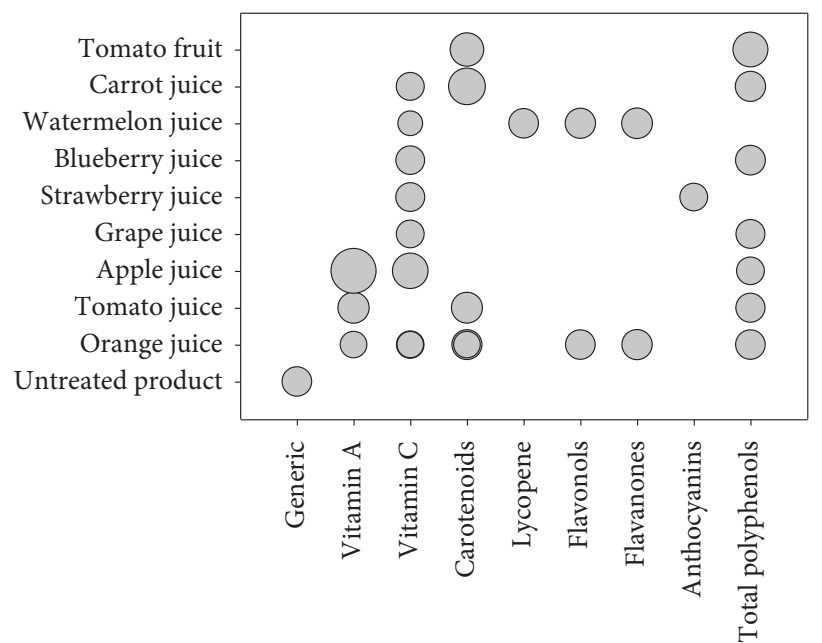

(c)

Figure 2: Effect of various treatments of different food products on the concentration of different bioactive compounds, with respect to a generic compound in an untreated product. (a) High-pressure processing; (b) high-pressure homogenization; (c) pulsed electric fields. Size of each bubble is related to the concentration of the bioactive compounds after the nonthermal treatment, with respect to the initial concentration.

In the dairy industry, homogenization has been extensively used for the stabilization of food emulsions and the disruption of fat globules. The higher operating pressures of $\mathrm{HPH} / \mathrm{UHPH}$ treatments enable also the direct microbial inactivation, the disruption of smaller particles, and the modification of proteins or other food constituents [124]. Figure 2(b) depicts the effects of HPH/UHPH treatment of different liquid food products on the concentration of different bioactive compounds.

For example, both HPH and UHPH treatments reported to induce a significant reduction of the suspended particle size distribution in juices $[121,125,126]$ and the juice viscosity $[125,127,128]$. Additionally, the color attributes of $\mathrm{HPH}$-treated juices are not significantly altered, in comparison with the untreated product $[121,122,125]$, whereas the cloudiness and opalescence stability are significantly improved $[123,126]$.
However, during pressure homogenization treatments, due to the significant temperature rise occurring in the homogenization valve, most of thermosensitive compounds, such as vitamins, carotenoids, and anthocyanins, are degraded to a higher extent than that by HPP. For example, when almond milk was treated at 200 or $300 \mathrm{MPa}$ and very high inlet temperature $\left(55-75^{\circ} \mathrm{C}\right)$, in order to obtain a microbiologically stable product, vitamin A was almost completely degraded [129]. However, in cloudy apple juice, a treatment, carried out at $100-175 \mathrm{MPa}$ for $3-5$ passes and an inlet temperature of $10-35^{\circ} \mathrm{C}$, caused a significant increase in the content of vitamin $A$ in the juice, with respect to the untreated product, due to the disruption effect on suspended vegetable cells.

Vitamins B1 and B2 were slightly reduced in almond milk treated for a single UHPH pass at $350 \mathrm{MPa}$ and an inlet temperature of $40^{\circ} \mathrm{C}[130]$. UHPH treatment caused a slight 
reduction in vitamin $\mathrm{C}$ in strawberry juice treated at higher pressure $(205 \mathrm{MPa})$ for 3 passes at an inlet temperature of $20^{\circ} \mathrm{C}$ [131]. The vitamin E content in soya milk was significantly affected by an UHPH treatment carried out at 200 or $300 \mathrm{MPa}$ and very high inlet temperature $\left(55-75^{\circ} \mathrm{C}\right)$, required to obtain a microbiologically stable product [132].

The total carotenoid content also exhibited a significant decrease upon HPH/UHPH processing, independently on the food matrix. In apple juice, treated for a single pass at pressures between 100 and $300 \mathrm{MPa}$ and inlet temperatures of $10-20^{\circ} \mathrm{C}$, a reduction in carotenoids of $30 \%$ was observed [133]. In orange juice, treated at the same conditions, the carotenoids decreased about $20 \%$ [134]. In tomato pulp, processed, because of its higher viscosity, at lower $\mathrm{HPH}$ pressures $(20-100 \mathrm{MPa})$ for 1 pass and an inlet temperature of $4^{\circ} \mathrm{C}$, a decrease in the total carotenoids of about 30\% was observed [135].

In contrast, the total polyphenols were well preserved by pressure homogenization treatments, independently on the food matrix. For example, in apple juice, treated for a single pass between 100 and $300 \mathrm{MPa}$ and an inlet temperature of $10-20^{\circ} \mathrm{C}$, the total polyphenols slightly increased [133]. In orange juice, treated under the same conditions, the total polyphenols remained constant [134]. In orange juice and grape juice, treated at $250 \mathrm{MPa}$ and room temperature, the total polyphenols slightly increased, with respect to untreated juices [136]. Similarly, mulberry juice, treated by $\mathrm{UHPH}$ at $200 \mathrm{MPa}$ for 3 passes and an inlet temperature of $4^{\circ} \mathrm{C}$, the total polyphenols remained constant [137]. Conversely, the same treatment had a detrimental effect on the anthocyanins of mulberry juice, with an observed reduction of almost 50\% [137].

Remarkably, the content of flavonoids exhibited a significant increase upon UHPH processing. For example, in soya milk, despite the treatment at high inlet temperatures $\left(55-75^{\circ} \mathrm{C}\right.$, with a single pass at 200 or $\left.300 \mathrm{MPa}\right)$, the flavonoids increased of about 20\% [132]. In orange juice, treated in the pressure range $(100-300 \mathrm{MPa})$ but at significantly lower inlet temperatures $\left(10-20^{\circ} \mathrm{C}\right)$, an even more significant increase in the content of flavonoids was observed, in comparison with untreated juice [134].

Pulsed electric field (PEF) technology is recognized to be a technique able to cause a significant microbial inactivation in beverages, while causing only a minimal impact both on the quality properties and on the content of health-beneficial compounds. This is mainly due to the low treatment temperature: although the intensity of PEF treatments might reach electric fields intensities up to $40 \mathrm{kV} / \mathrm{cm}$ and a total energy delivered to the product of $40-100 \mathrm{~kJ} / \mathrm{L}$ [61], the product temperature can be maintained below $40^{\circ} \mathrm{C}[138,139]$.

Figure 2(c) clearly shows that, in different fruit and vegetable juices, no significant decreases are observed among the main health-beneficial compounds, including vitamins, carotenoids, and phenolic compounds. In contrast, in some cases, a significant increase is observed, which can be attributed to the enhanced extraction of bioactives from the vegetable cells [140].

In particular, vitamin $\mathrm{A}$ is observed to only slightly decrease of less than $10 \%$ in orange juice [141], but to significantly increase in apple [61] and in tomato juice [138].
Similarly, the vitamin C retention was always very high, comprised between 90 and 100\%, independently on the food matrix [139, 142-145]. In the case of carotenoids, the PEF treatments did not cause any significant decrease in concentration in orange juice $[141,146]$, tomato juice [138], and watermelon juice [144] and a measurable increase $(+25 \%)$ in carrot juice [147].

In addition, no significant variation was observed for flavonols in orange [148] or watermelon juice [144], for flavanones in orange juice $[146,148]$ or watermelon juice [144], for anthocyanins in strawberry juice [139], for total polyphenols in apple [145], or in orange [148], in grape [145], in blueberry [142], in tomato [139], and in carrot juices [147].

Ultrasound is thought to enhance the destabilization of casein micelles in milk [149]. This can be used to advantage in the coagulation of various milk sources, for example, goats' milk and reconstituted milk. Goats' milk is known for its weaker coagulation abilities as compared to cows' milk. The use of ultrasound treatment prior to addition of rennet resulted in smaller and more uniform particle sizes in the coagulant formed $[150,151]$. Ultrasonically treated milk and yogurt samples also showed an increase in the gel firmness, coagulum strength, final storage modulus, cohesiveness, and water holding capacity [152]. These factors were stated to be due to a decrease in the soluble proteins and an increase in insoluble high-molecular-weight coaggregates formed as a result of protein denaturization on sonication $[153,154]$.

Monteiro et al. [155] noticed that ultrasound energy affects the physical properties of chocolate milk and the subsequent size distribution of fat globules and resultant rheological behavior of the treated sample; however, the bioactive compounds present and the nutritional quality of the product were still maintained. Changes to food materials is dependent in the first case on the frequency employed for sonication whether physical or mechanical changes are required, thus employing lower frequencies, or whether chemical changes are required where higher frequencies would be of more benefit.

Supercritical drying with the use of supercritical fluids $\left(\mathrm{CO}_{2}\right)$ is used as an alternative process to conventional drying techniques [156]. Carbon dioxide $\left(\mathrm{CO}_{2}\right)$ at high pressures $(7.0$ to $30.0 \mathrm{MPa})$ or in supercritical phase (above $\left.31^{\circ} \mathrm{C}, 7.3 \mathrm{MPa}\right)$ is considered as a novel nonthermal technology [157]. This preservation technology achieves inactivation of microorganisms and also meets consumers' demands for a product with high nutritional and sensory qualities [158]. Its main advantage is operation at relatively low temperature that avoids the thermal effects of traditional heat preservation, retaining the food freshness [159].

In food application field, nonthermal plasma (NTP) comes in various ways, from food surface application to direct in liquid food application. NTP is effective and causes minor harm to the exposed materials, such as biological samples or processed foods or packaging materials [160]. Researches have been mostly exploring plasma effect on inactivation of microorganisms [161, 162], but lately, plasma effect on food ingredients becomes focus topic due to combined physicochemical effects and complexed food 


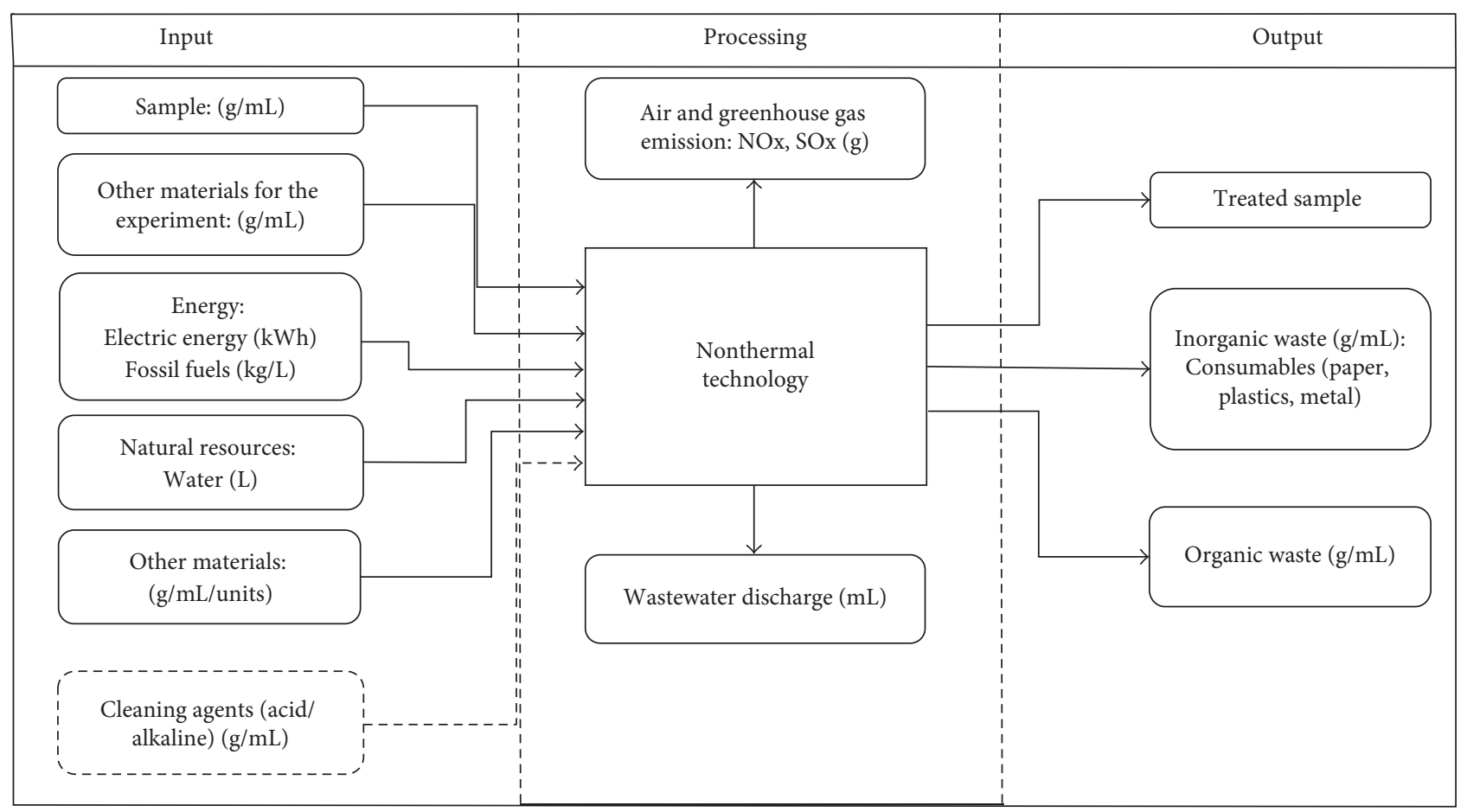

FIGURE 3: Generic model of using nonthermal technologies. Rounded rectangles outlined in solid lines present direct inputs and outputs; rounded rectangles outlined in dashed lines present inputs/outputs not directly related to nonthermal technologies.

structure. Plasma application in/on food brings another perspective of possible negative effects on phenolic compounds due to production of oxidative species.

Grzegorzewski et al. [163] have noted a degradation of phenolic compounds in lamb's lettuce after NTP treatment, but Misra et al. [164] have reported that cold plasma treatments had no significant effect on anthocyanins in strawberries and that, at the same time, phenolic acids have remained unchanged. Regarding liquid food, like fruit juices, an increase in total phenolic content [165] and anthocyanin content [166] in pomegranate juice after plasma treatment has been observed, as well as an increase in anthocyanin and phenolic acid contents in sour cherry Marasca juice [167] has been observed. Lukić et al. [168] report effects of plasma treatment on wines (red wine Cabernet Sauvignon and white wine Graševina) which have resulted in slight changes of chromatic characteristics and in reduction of phenolic compounds in both red and white wines, including total phenolics, total anthocyanins, total tannins, and certain free anthocyanins, while the concentrations of the most individual phenolic acids and flavan-3-ols slightly increased. These results led to new opening field of plasma treatment as a new extraction method due to improvement in the extraction of phenolic and other compounds.

\section{Importance of Analyzing Environmental Impacts of Nonthermal Food Technologies}

Besides obtaining safe products with high quality with nonthermal technologies, food processors are increasing their interest in reducing the environmental footprint of the products and the processing cost [169]. However, analysis and comparison of environmental impacts of nonthermal technologies pose a challenge mainly because of the differences in the scale of the facilities and food processed (meat, egg, fruit, vegetables, liquid food, etc.). In most of the cases, these techniques are not implemented in large-scale industrial facilities and are often studied on lab scale or pilot level without deep analysis of the complete process [170].

Technologies, such as pulsed electric field treatment or high-pressure treatment, not only achieve microbial inactivation under mild conditions or inactivate certain enzymes and prevent undesired changes in food but also decrease processing time and decrease energy consuming $[6,171]$.

In analyzing nonthermal technologies, it is common to use the life cycle assessment (LCA) approach. It is a scientific method that includes mapping the process, setting the scope and boundaries, collecting data, calculating, evaluating, and interpreting the results with the aim to propose environmental improvements [172]. Hospido et al. [170] stress the difficulties in evaluating environmental impact of these technologies in terms of (i) the lack of real data for the inventory phase, which is often based on lab-scale information or theoretical data; (ii) the definition of the functional unit for comparative studies since new products or processes might have unique properties; and (iii) that manufacture of products or processes can be expected to start several years ahead and assumptions on surrounding systems will be required. Once the technologies are transferred from labs to real production plants, novel processing technologies can be compared with existing commercial alternatives and environmental hotspots can be identified [173]. 
Evaluation of environmental impact of novel technologies is usually performed using a partial life cycle assessment (LCA) approach. It included mapping the process of novel food treatments, setting scope and boundaries as lab scale, collecting and calculating data, and evaluating the results [172]. Functional unit (FU) as an output reference may be set as $1 \mathrm{~kg} / 1 \mathrm{~L}$ of treated food product. Figure 3 depicts the generic system boundaries.

There are some comparative LCA studies of conventional and novel technologies. Pardo and Zufía [174] evaluated the environmental impacts of some traditional and novel food preservation technologies with the aim to contribute to the development of more sustainable food products. Some general improvements were identified, and environmental criteria were provided in order to select the more adequate preservation method when designing new food products. Valsasina et al. [175] compared ultrahighpressure homogenization with common thermal treatment for milk. The upscaling showed a decrease in carbon footprint up to $88 \%$ achievable with improvements in efficiency.

Aganovic et al. [176] studied the energy balance and LCA of pulsed electric fields and high-pressure processing technologies in comparison with conventional thermal processing applied to the preservation of tomato and watermelon juices. However, at a pilot scale, both pulsed electric field and highpressure processing technologies presented higher energy consumption expressed per liter of juice, indicating the necessity for further optimization of the process.

\section{Future Challenges of Novel Nonthermal Technologies and Conclusion}

Legislation on hygienic design of food-processing equipment is rather vague [34]. Considering that there are a large number of different types of standards and regulations related to hygienic design and due to the redundancy of many requirements, a compact tool for evaluating novel technologies is more than needed [33].

In the future, studies related to comparison of environmental impacts of novel and conventional techniques will need to go in two directions: (i) improving the environmental performance of nonthermal technologies per se, and (ii) comparing environmental aspects of nonthermal and conventional technologies, along with weighting other factors such as quality of the final product or investment costs [2].

\section{Conflicts of Interest}

The authors confirm that there are no conflicts of interest associated with this publication.

\section{Acknowledgments}

A. Režek Jambrak, F. Donsi, and T. Vukušić acknowledge Croatian Science Foundation for financial support of the project "High voltage discharges for green solvent extraction of bioactive compounds from Mediterranean herbs" (IP2016-06-1913). A. Režek Jambrak and I. Djekic acknowledge
COST Action CA15118, "Mathematical and Computer Science Methods for Food Science and Industry."

\section{References}

[1] A. R. Jambrak, M. Šimunek, S. Evačić, K. Markov, G. Smoljanić, and J. Frece, "Influence of high power ultrasound on selected moulds, yeasts and Alicyclobacillus acidoterrestris in apple, cranberry and blueberry juice and nectar," Ultrasonics, vol. 83, pp. 3-17, 2018.

[2] I. Djekic, N. Sanjuán, G. Clemente et al., "Review on environmental models in the food chain-current status and future perspectives," Journal of Cleaner Production, vol. 176, pp. 1012-1025, 2018.

[3] N. Misra, A. Martynenko, F. Chemat, L. Paniwnyk, F. J. Barba, and A. R. Jambrak, "Thermodynamics, transport phenomena, and electrochemistry of external field-assisted nonthermal food technologies," Critical Reviews in Food Science and Nutrition, vol. 58, no. 11, pp. 1832-1863, 2017.

[4] T. Bolumar, E. Georget, and A. Mathys, "High pressure processing (HPP) of foods and its combination with electron beam processing," in Electron Beam Pasteurization and Complementary Food Processing Technologies, pp. 127-155, Elsevier, New York, NY, USA, 2015.

[5] V. P. Valdramidis, "Chapter 14-modeling the kinetics of microbial and quality attributes of fluid food during novel thermal and non-thermal processes," in Novel Thermal and Non-Thermal Technologies for Fluid Foods, pp. 433-471, Academic Press, San Diego, CA, USA, 2012.

[6] C. Jermann, T. Koutchma, E. Margas, C. Leadley, and V. RosPolski, "Mapping trends in novel and emerging food processing technologies around the world," Innovative Food Science and Emerging Technologies, vol. 31, pp. 14-27, 2015.

[7] L. Leistner, "Basic aspects of food preservation by hurdle technology," International Journal of Food Microbiology, vol. 55, no. 1-3, pp. 181-186, 2000.

[8] F. Devlieghere, L. Vermeiren, and J. Debevere, "New preservation technologies: possibilities and limitations," International Dairy Journal, vol. 14, no. 4, pp. 273-285, 2004.

[9] A. Rajkovic, N. Smigic, and F. Devlieghere, "Contemporary strategies in combating microbial contamination in food chain," International Journal of Food Microbiology, vol. 141, pp. S29-S42, 2010.

[10] A. Tremarin, T. R. Brandão, and C. L. Silva, "Application of ultraviolet radiation and ultrasound treatments for Alicyclobacillus acidoterrestris spores inactivation in apple juice," LWT-Food Science and Technology, vol. 78, pp. 138-142, 2017.

[11] L. Han, S. Patil, D. Boehm, V. Milosavljević, P. J. Cullen, and P. Bourke, "Mechanisms of inactivation by high-voltage atmospheric cold plasma differ for Escherichia coli and Staphylococcus aureus," Applied and Environmental Microbiology, vol. 82, no. 2, pp. 450-458, 2016.

[12] D. Ziuzina, L. Han, P. J. Cullen, and P. Bourke, "Cold plasma inactivation of internalised bacteria and biofilms for Salmonella enterica serovar Typhimurium, Listeria monocytogenes and Escherichia coli," International Journal of Food Microbiology, vol. 210, pp. 53-61, 2015.

[13] J. Li, Y. Suo, X. Liao et al., "Analysis of Staphylococcus aureus cell viability, sublethal injury and death induced by synergistic combination of ultrasound and mild heat," Ultrasonics Sonochemistry, vol. 39, pp. 101-110, 2017.

[14] E. Luengo, I. Álvarez, and J. Raso, "Improving carotenoid extraction from tomato waste by pulsed electric fields," Frontiers in Nutrition, vol. 1, p. 12, 2014. 
[15] P. Khandpur and P. R. Gogate, "Effect of novel ultrasound based processing on the nutrition quality of different fruit and vegetable juices," Ultrasonics Sonochemistry, vol. 27, pp. 125-136, 2015.

[16] M. Vinceković, M. Viskić, S. Jurić et al., "Innovative technologies for encapsulation of Mediterranean plants extracts," Trends in Food Science and Technology, vol. 69, pp. 1-12, 2017.

[17] A. Prakash, "Non-thermal processing technologies to improve the safety of nuts," in Improving the Safety and Quality of Nuts, pp. 35-55, Elsevier, New York, NY, USA, 2013.

[18] L. Han, D. Ziuzina, C. Heslin et al., "Controlling microbial safety challenges of meat using high voltage atmospheric cold plasma," Frontiers in Microbiology, vol. 7, p. 977, 2016.

[19] V. Guillard, O. Couvert, V. Stahl et al., "Validation of a predictive model coupling gas transfer and microbial growth in fresh food packed under modified atmosphere," Food Microbiology, vol. 58, pp. 43-55, 2016.

[20] M. Glueck, B. Schamberger, P. Eckl, and K. Plaetzer, "New horizons in microbiological food safety: photodynamic decontamination based on a curcumin derivative," Photochemical and Photobiological Sciences, vol. 16, no. 12, pp. 1784-1791, 2017.

[21] K. Vilkhu, R. Mawson, L. Simons, and D. Bates, "Applications and opportunities for ultrasound assisted extraction in the food industry-a review," Innovative Food Science and Emerging Technologies, vol. 9, no. 2, pp. 161-169, 2008.

[22] L. M. Anaya-Esparza, R. M. Velázquez-Estrada, A. X. Roig, H. S. García-Galindo, S. G. Sayago-Ayerdi, and E. MontalvoGonzález, "Thermosonication: an alternative processing for fruit and vegetable juices," Trends in Food Science and Technology, vol. 61, pp. 26-37, 2017.

[23] A. Režek Jambrak, V. Lelas, Z. Herceg et al., "Advantages and disadvantages of high power ultrasound application in the dairy industry," Mljekarstvo: časopis za unaprjeđenje proizvodnje i prerade mlijeka, vol. 59, no. 4, pp. 267-281, 2009.

[24] D. Pingret, G. Durand, A.-S. Fabiano-Tixier, A. Rockenbauer, C. Ginies, and F. Chemat, "Degradation of edible oil during food processing by ultrasound: electron paramagnetic resonance, physicochemical, and sensory appreciation," Journal of Agricultural and Food Chemistry, vol. 60, no. 31, pp. 77617768, 2012.

[25] D. Pingret, A.-S. Fabiano-Tixier, and F. Chemat, "Degradation during application of ultrasound in food processing: a review," Food Control, vol. 31, no. 2, pp. 593-606, 2013.

[26] IFT, Kinetics of Microbial Inactivation for Alternative Food Processing Technologies, Institute of Food Technologists, Chicago, IL, USA, 2000.

[27] NACMCF, "Requisite scientific parameters for establishing the equivalence of alternative methods of pasteurization," Journal of Food Protection, vol. 69, no. 5, pp. 1190-1216, 2006.

[28] T. Koutchma, "Advances in ultraviolet light technology for non-thermal processing of liquid foods," Food and Bioprocess Technology, vol. 2, no. 2, pp. 138-155, 2009.

[29] EC, "Technology readiness levels (TRL)," in Horizon 2020-Work Programme 2014-2015 General Annexes, Extract from Part 19-Commission Decision C, European Commission, Brussels, Belgium, 2014.

[30] J. Howlett, D. G. Edwards, A. Cockburn et al., "The safety assessment of novel foods and concepts to determine their safety in use," International Journal of Food Sciences and Nutrition, vol. 54, no. 5, pp. 1-32, 2003.

[31] H.-R. Koch, "Designed for cleanability: hygienic design enclosure meets the high demands of the food industry,"
Trends in Food Science and Technology, vol. 20, no. 1, pp. S53-S56, 2009.

[32] EHEDG, EHEDG Glossary, European Hygienic Engineering and Design Group, Brussels, Belgium, 2013.

[33] G. Betta, D. Barbanti, and R. Massini, "Food hygiene in aseptic processing and packaging system: a survey in the Italian food industry," Trends in Food Science and Technology, vol. 22, no. 6, pp. 327-334, 2011.

[34] K. Aarnisalo, K. Tallavaara, G. Wirtanen, R. Maijala, and L. Raaska, "The hygienic working practices of maintenance personnel and equipment hygiene in the Finnish food industry," Food Control, vol. 17, no. 12, pp. 1001-1011, 2006.

[35] EC, Regulation (EC) no 852/2004 of the European Parliament and of the Council of 29 April 2004 on the Hygiene of Foodstuffs, Official Journal of European Union, European Commission, Brussels, Belgium, 2004.

[36] EHEDG, Hygienic Equipment Design Criteria, European Hygienic Engineering and Design Group, Brussels, Belgium, 2004.

[37] NSF, NSF/ANSI 51-2012 Food Equipment Materials, NSF International Standard/American National Standard, Ann Arbor, MI, USA, 2012.

[38] AMI, Sanitary Equipment Design Principles: Checklist \& Glossary, in Sanitary Equipment Design Taskforce, American Meat Institute Foundation, Washington, DC, USA, 2014.

[39] ISO, ISO 4287:1997 Geometrical Product Specifications (GPS)-Surface Texture: Profile Method-Terms, Definitions and Surface Texture Parameters, International Organization for Standardization, Geneva, Switzerland, 1997.

[40] E. Rendueles, M. K. Omer, O. Alvseike, C. Alonso-Calleja, R. Capita, and M. Prieto, "Microbiological food safety assessment of high hydrostatic pressure processing: a review," LWT-Food Science and Technology, vol. 44, no. 5, pp. 12511260, 2011.

[41] K. Huang, H. Tian, L. Gai, and J. Wang, "A review of kinetic models for inactivating microorganisms and enzymes by pulsed electric field processing," Journal of Food Engineering, vol. 111, no. 2, pp. 191-207, 2012.

[42] S. J. Ramos, M. Chiquirrín, S. García, S. Condón, and M. D. Pérez, "Effect of high pressure treatment on inactivation of vegetative pathogens and on denaturation of whey proteins in different media," LWT-Food Science and Technology, vol. 63, no. 1, pp. 732-738, 2015.

[43] F. Noci, M. Walkling-Ribeiro, D. A. Cronin, D. J. Morgan, and J. G. Lyng, "Effect of thermosonication, pulsed electric field and their combination on inactivation of Listeria innocua in milk," International Dairy Journal, vol. 19, no. 1, pp. 30-35, 2009.

[44] F. Chemat, N. Rombaut, A.-G. Sicaire, A. Meullemiestre, A.-S. Fabiano-Tixier, and M. Abert-Vian, "Ultrasound assisted extraction of food and natural products. Mechanisms, techniques, combinations, protocols and applications: a review," Ultrasonics Sonochemistry, vol. 34, pp. 540-560, 2017.

[45] A. Muñoz, I. M. Caminiti, I. Palgan et al., "Effects on Escherichia coli inactivation and quality attributes in apple juice treated by combinations of pulsed light and thermosonication," Food Research International, vol. 45, no. 1, pp. 299-305, 2012.

[46] I. M. Caminiti, F. Noci, A. Muñoz et al., "Impact of selected combinations of non-thermal processing technologies on the quality of an apple and cranberry juice blend," Food Chemistry, vol. 124, no. 4, pp. 1387-1392, 2011. 
[47] E. Kvam, B. Davis, F. Mondello, and A. L. Garner, "Nonthermal atmospheric plasma rapidly disinfects multidrugresistant microbes by inducing cell surface damage," Antimicrobial Agents and Chemotherapy, vol. 56, no. 4, pp. 2028-2036, 2012.

[48] P. Khandpur and P. R. Gogate, "Evaluation of ultrasound based sterilization approaches in terms of shelf life and quality parameters of fruit and vegetable juices," Ultrasonics Sonochemistry, vol. 29, pp. 337-353, 2016.

[49] D.-W. Sun, Emerging Technologies for Food Processing, Elsevier, New York, NY, USA, 2014.

[50] F. V. Silva, E. K. Tan, and M. Farid, "Bacterial spore inactivation at $45-65^{\circ} \mathrm{C}$ using high pressure processing: study of Alicyclobacillus acidoterrestris in orange juice," Food Microbiology, vol. 32, no. 1, pp. 206-211, 2012.

[51] J. Pinela and I. C. Ferreira, "Nonthermal physical technologies to decontaminate and extend the shelf-life of fruits and vegetables: trends aiming at quality and safety," Critical Reviews in Food Science and Nutrition, vol. 57, no. 10, pp. 2095-2111, 2017.

[52] B. Tiwari, K. Muthukumarappan, C. P. O’Donnell, and P. J. Cullen, "Inactivation kinetics of pectin methylesterase and cloud retention in sonicated orange juice," Innovative Food Science and Emerging Technologies, vol. 10, no. 2, pp. 166-171, 2009.

[53] N. N. Misra, "The contribution of non-thermal and advanced oxidation technologies towards dissipation of pesticide residues," Trends in Food Science and Technology, vol. 45, no. 2, pp. 229-244, 2015.

[54] D. Millan-Sango, L. Han, V. Milosavljevic et al., “Assessing bacterial recovery and efficacy of cold atmospheric plasma treatments," Food and Bioproducts Processing, vol. 96, pp. 154-160, 2015.

[55] G. Marx, A. Moody, and D. Bermúdez-Aguirre, "A comparative study on the structure of Saccharomyces cerevisiae under nonthermal technologies: high hydrostatic pressure, pulsed electric fields and thermo-sonication," International Journal of Food Microbiology, vol. 151, no. 3, pp. 327-337, 2011.

[56] G. J. Price, "The use of ultrasound for the controlled degradation of polymer solutions," Advances in Sonochemistry, vol. 1, pp. 231-287, 1990.

[57] H. Alpas, N. Kalchayanand, F. Bozoglu, A. Sikes, C. P. Dunne, and B. Ray, "Variation in resistance to hydrostatic pressure among strains of food-borne pathogens," Applied and Environmental Microbiology, vol. 65, no. 9, pp. 4248-4251, 1999.

[58] M. Linton, M. F. Patterson, and M. Patterson, "High pressure processing of foods for microbiological safety and quality," Acta Microbiologica et Immunologica Hungarica, vol. 47, no. 2-3, pp. 175-182, 2000.

[59] J. Smelt, "Recent advances in the microbiology of high pressure processing," Trends in Food Science and Technology, vol. 9, no. 4, pp. 152-158, 1998.

[60] M. Patterson, "Microbiology of pressure-treated foods," Journal of Applied Microbiology, vol. 98, no. 6, pp. 1400-1409, 2005.

[61] F. Donsì, G. Ferrari, P. Maresca et al., "Effects of emerging technologies on food quality," in Food Quality: Control, Analysis and Consumer Concerns, D. A. Medina and A. M. Laine, Eds., Nova Science Publishers, Hauppauge, NY, USA, 2011.

[62] S. Sharabi, Z. Okun, and A. Shpigelman, "Changes in the shelf life stability of riboflavin, vitamin $\mathrm{C}$ and antioxidant properties of milk after (ultra) high pressure homogenization: direct and indirect effects," Innovative Food Science and Emerging Technologies, vol. 47, pp. 161-169, 2018.

[63] M.-C. Michalski and C. Januel, "Does homogenization affect the human health properties of cow's milk?," Trends in Food Science and Technology, vol. 17, no. 8, pp. 423-437, 2006.

[64] A. M. Diels and C. W. Michiels, "High-pressure homogenization as a non-thermal technique for the inactivation of microorganisms," Critical Reviews in Microbiology, vol. 32, no. 4, pp. 201-216, 2006.

[65] F. Donsì, G. Ferrari, E. Lenza, and P. Maresca, "Main factors regulating microbial inactivation by high-pressure homogenization: operating parameters and scale of operation," Chemical Engineering Science, vol. 64, no. 3, pp. 520-532, 2009.

[66] F. Donsì, M. Annunziata, and G. Ferrari, "Microbial inactivation by high pressure homogenization: effect of the disruption valve geometry," Journal of Food Engineering, vol. 115, no. 3, pp. 362-370, 2013.

[67] F. Donsì, G. Ferrari, and P. Maresca, "High-pressure homogenization for food sanitization," in Global Issues in Food Science and Technology, pp. 309-352, Elsevier, New York, NY, USA, 2009.

[68] N. Datta, M. G. Hayes, H. C. Deeth, and A. L. Kelly, "Significance of frictional heating for effects of high pressure homogenisation on milk," Journal of Dairy Research, vol. 72, no. 4, pp. 393-399, 2005.

[69] J. Vachon, E. E. Kheadr, J. Giasson, P. Paquin, and I. Fliss, "Inactivation of foodborne pathogens in milk using dynamic high pressure," Journal of Food Protection, vol. 65, no. 2, pp. 345-352, 2002.

[70] E. Y. Wuytack, A. M. Diels, and C. W. Michiels, "Bacterial inactivation by high-pressure homogenisation and high hydrostatic pressure," International Journal of Food Microbiology, vol. 77, no. 3, pp. 205-212, 2002.

[71] J. Geciova, D. Bury, and P. Jelen, "Methods for disruption of microbial cells for potential use in the dairy industry-a review," International Dairy Journal, vol. 12, no. 6, pp. 541-553, 2002.

[72] L. Gracin, A. R. Jambrak, H. Juretić et al., "Influence of high power ultrasound on Brettanomyces and lactic acid bacteria in wine in continuous flow treatment," Applied Acoustics, vol. 103, pp. 143-147, 2016.

[73] S. Gao, G. D. Lewis, M. Ashokkumar, and Y. Hemar, "Inactivation of microorganisms by low-frequency high-power ultrasound: 1. Effect of growth phase and capsule properties of the bacteria," Ultrasonics Sonochemistry, vol. 21, no. 1, pp. 446-453, 2014.

[74] N. F. Beatty and M. K. Walsh, "Influence of thermosonication on Geobacillus stearothermophilus inactivation in skim milk," International Dairy Journal, vol. 61, pp. 10-17, 2016.

[75] H. Alighourchi, M. Barzegar, M. A. Sahari, and S. Abbasi, "The effects of sonication and gamma irradiation on the inactivation of Escherichia coli and Saccharomyces cerevisiae in pomegranate juice," Iranian Journal of Microbiology, vol. 6, no. 1, pp. 51-58, 2014.

[76] A. Bevilacqua, D. Campaniello, M. Sinigaglia, and M. R. Corbo, "Combination of ultrasound and antimicrobial compounds towards Pichia spp. and Wickerhamomyces anomalus in pineapple juice," LWT-Food Science and Technology, vol. 64, no. 2, pp. 616-622, 2015.

[77] A. Bevilacqua, B. Speranza, D. Campaniello, M. Sinigaglia, and M. R. Corbo, "Inactivation of spoiling yeasts of fruit 
juices by pulsed ultrasound," Food and Bioprocess Technology, vol. 7, no. 8, pp. 2189-2197, 2014.

[78] N. D. S. Cruz-Cansino, I. Reyes-Hernández, L. DelgadoOlivares, D. P. Jaramillo-Bustos, J. A. Ariza-Ortega, and E. Ramírez-Moreno, "Effect of ultrasound on survival and growth of Escherichia coli in cactus pear juice during storage," Brazilian Journal of Microbiology, vol. 47, no. 2, pp. 431-437, 2016.

[79] T. Erkaya, M. Başlar, M. Şengül, and M. F. Ertugay, "Effect of thermosonication on physicochemical, microbiological and sensorial characteristics of ayran during storage," Ultrasonics Sonochemistry, vol. 23, pp. 406-412, 2015.

[80] F. V. Silva, "High pressure processing pretreatment enhanced the thermosonication inactivation of Alicyclobacillus acidoterrestris spores in orange juice," Food Control, vol. 62, pp. 365-372, 2016.

[81] M. Ferrario, S. M. Alzamora, and S. Guerrero, "Study of the inactivation of spoilage microorganisms in apple juice by pulsed light and ultrasound," Food Microbiology, vol. 46, pp. 635-642, 2015.

[82] M. Ferrario and S. Guerrero, "Effect of a continuous flowthrough pulsed light system combined with ultrasound on microbial survivability, color and sensory shelf life of apple juice," Innovative Food Science and Emerging Technologies, vol. 34, pp. 214-224, 2016.

[83] G. Marchesini, L. Fasolato, E. Novelli et al., "Ultrasonic inactivation of microorganisms: a compromise between lethal capacity and sensory quality of milk," Innovative Food Science and Emerging Technologies, vol. 29, pp. 215-221, 2015.

[84] Ç. U. Pala, N. N. D. Zorba, and G. Özcan, "Microbial inactivation and physicochemical properties of ultrasound processed pomegranate juice," Journal of Food Protection, vol. 78, no. 3, pp. 531-539, 2015.

[85] B. H. Samani, M. H. Khoshtaghaza, Z. Lorigooini, S. Minaei, and H. Zareiforoush, "Analysis of the combinative effect of ultrasound and microwave power on Saccharomyces cerevisiae in orange juice processing," Innovative Food Science and Emerging Technologies, vol. 32, pp. 110-115, 2015.

[86] K. Huang, S. Wrenn, R. Tikekar, and N. Nitin, "Efficacy of decontamination and a reduced risk of cross-contamination during ultrasound-assisted washing of fresh produce," Journal of Food Engineering, vol. 224, pp. 95-104, 2017.

[87] A. Kassem, J. Meade, K. McGill et al., "An investigation of high intensity ultrasonication and chemical immersion treatments on Campylobacter jejuni and spoilage bacteria in chicken," Innovative Food Science and Emerging Technologies, vol. 45, pp. 298-305, 2018.

[88] G. Özcan and N. N. Demirel Zorba, "Combined effect of ultrasound and essential oils to reduce Listeria monocytogenes on fresh produce," Food Science and Technology International, vol. 22, no. 4, pp. 353-362, 2016.

[89] J. Liu, L. Li, L. Zhou, B. Li, and Z. Xu, "Effect of ultrasound treatment conditions on Saccharomyces cerevisiae by response surface methodology," Microbial Pathogenesis, vol. 111, pp. 497-502, 2017.

[90] D. Kang, Y. Jiang, L. Xing, G. Zhou, and W. Zhang, "Inactivation of Escherichia coli O157:H7 and Bacillus cereus by power ultrasound during the curing processing in brining liquid and beef," Food Research International, vol. 102, pp. 717-727, 2017.

[91] J. J. Sienkiewicz, A. Wesołowski, W. Stankiewicz, and R. Kotowski, "The influence of ultrasonic treatment on the growth of the strains of Salmonella enterica subs. typhimurium," Journal of Food Science and Technology, vol. 54, no. 8, pp. 2214-2223, 2017.

[92] L. Milne, I. Stewart, and D. H. Bremner, "Comparison of hydroxyl radical formation in aqueous solutions at different ultrasound frequencies and powers using the salicylic acid dosimeter," Ultrasonics Sonochemistry, vol. 20, no. 3, pp. 984-989, 2013.

[93] D. Comeskey, O. A. Larparadsudthi, T. J. Mason, and L. Paniwnyk, "The use of a range of ultrasound frequencies to reduce colouration caused by dyes," Water Science and Technology, vol. 66, no. 10, pp. 2251-2257, 2012.

[94] D.-c. Kang, Y.-h. Zou, Y.-p. Cheng, L.-j. Xing, G.-h. Zhou, and W.-g. Zhang, "Effects of power ultrasound on oxidation and structure of beef proteins during curing processing," Ultrasonics Sonochemistry, vol. 33, pp. 47-53, 2016.

[95] D.-c. Kang, X.-q. Gao, Q.-f. Ge, G.-h. Zhou, and W.-g. Zhang, "Effects of ultrasound on the beef structure and water distribution during curing through protein degradation and modification," Ultrasonics Sonochemistry, vol. 38, pp. 317-325, 2017.

[96] J. Sun, X. Li, X. Lin et al., "Sonodegradation of cyanidin-3glucosylrutinoside: degradation kinetic analysis and its impact on antioxidant capacity in vitro," Journal of the Science of Food and Agriculture, vol. 97, no. 5, pp. 1475-1481, 2017.

[97] G.-L. Yao, X.-H. Ma, X.-Y. Cao, and J. Chen, "Effects of power ultrasound on stability of cyanidin-3-glucoside obtained from blueberry," Molecules, vol. 21, no. 11, p. 1564, 2016.

[98] K. Tsikrika, B.-S. Chu, D. H. Bremner, and M. Adília Lemos, "The effect of different frequencies of ultrasound on the activity of horseradish peroxidase," LWT-Food Science and Technology, vol. 89, pp. 591-595, 2018.

[99] S. K. Vanga, A. Singh, and V. Raghavan, "Review of conventional and novel food processing methods on food allergens," Critical Reviews in Food Science and Nutrition, vol. 57, no. 10, pp. 2077-2094, 2017.

[100] N. V. Olsen, K. G. Grunert, and A.-M. Sonne, "Consumer acceptance of high-pressure processing and pulsed-electric field: a review," Trends in Food Science and Technology, vol. 21, no. 9, pp. 464-472, 2010.

[101] E. Walther, B. Nagengast, and C. Trasselli, "Evaluative conditioning in social psychology: facts and speculations," Cognition and Emotion, vol. 19, no. 2, pp. 175-196, 2005.

[102] B. De Ancos, S. Sgroppo, L. Plaza, and M. P. Cano, "Possible nutritional and health-related value promotion in orange juice preserved by high-pressure treatment," Journal of the Science of Food and Agriculture, vol. 82, no. 8, pp. 790-796, 2002.

[103] P. Butz, A. Fernández Garća, R. Lindauer, S. Dieterich, A. Bognár, and B. Tauscher, "Influence of ultra high pressure processing on fruit and vegetable products," Journal of Food Engineering, vol. 56, no. 2-3, pp. 233-236, 2003.

[104] L. Daoudi, J. M. Quevedo, A. J. Trujillo et al., "Effects of highpressure treatment on the sensory quality of white grape juice," International Journal of High Pressure Research, vol. 22, no. 3-4, pp. 705-709, 2002.

[105] A. F. García, P. Butz, A. Bognàr, and B. Tauscher, "Antioxidative capacity, nutrient content and sensory quality of orange juice and an orange-lemon-carrot juice product after high pressure treatment and storage in different packaging," European Food Research and Technology, vol. 213, no. 4-5, pp. 290-296, 2001.

[106] G. Ferrari, P. Maresca, and R. Ciccarone, "The application of high hydrostatic pressure for the stabilization of functional 
foods: pomegranate juice," Journal of Food Engineering, vol. 100, no. 2, pp. 245-253, 2010.

[107] G.-C. Yen and H.-T. Lin, "Changes in volatile flavor components of guava juice with high-pressure treatment and heat processing and during storage," Journal of Agricultural and Food Chemistry, vol. 47, no. 5, pp. 2082-2087, 1999.

[108] M. E. Parish, "Orange juice quality after treatment by thermal pasteurization or isostatic high pressure," LWTFood Science and Technology, vol. 31, no. 5, pp. 439-442, 1998.

[109] A. Polydera, N. Stoforos, and P. Taoukis, "Effect of high hydrostatic pressure treatment on post processing antioxidant activity of fresh Navel orange juice," Food Chemistry, vol. 91, no. 3, pp. 495-503, 2005.

[110] K.-C. Hsu, "Evaluation of processing qualities of tomato juice induced by thermal and pressure processing," $L W T$ Food Science and Technology, vol. 41, no. 3, pp. 450-459, 2008.

[111] D. Knorr, "Effects of high-hydrostatic-pressure processes on food safety and quality," Food Technology, vol. 47, no. 6, pp. 156-161, 1993.

[112] C. Sánchez-Moreno, L. Plaza, B. de Ancos, and M. Pilar Cano, "Vitamin C, provitamin A carotenoids, and other carotenoids in high-pressurized orange juice during refrigerated storage," Journal of Agricultural and Food Chemistry, vol. 51, no. 3, pp. 647-653, 2003.

[113] F. J. Barba, M. J. Esteve, and A. Frigola, "Physicochemical and nutritional characteristics of blueberry juice after high pressure processing," Food Research International, vol. 50, no. 2, pp. 545-549, 2013.

[114] C. M. Wolbang, J. L. Fitos, and M. T. Treeby, "The effect of high pressure processing on nutritional value and quality attributes of Cucumis melo L.," Innovative Food Science and Emerging Technologies, vol. 9, no. 2, pp. 196-200, 2008.

[115] A. Westphal, U. Schwarzenbolz, and V. Böhm, "Effects of high pressure processing on bioactive compounds in spinach and rosehip puree," European Food Research and Technology, vol. 244, no. 3, pp. 395-407, 2017.

[116] M. Clariana, L. Guerrero, C. Sárraga, and J. A. GarciaRegueiro, "Effects of high pressure application (400 and 900 $\mathrm{MPa}$ ) and refrigerated storage time on the oxidative stability of sliced skin vacuum packed dry-cured ham," Meat Science, vol. 90, no. 2, pp. 323-329, 2012.

[117] C. Zuluaga, A. Martínez, J. Fernández, J. López-Baldó, A. Quiles, and D. Rodrigo, "Effect of high pressure processing on carotenoid and phenolic compounds, antioxidant capacity, and microbial counts of bee-pollen paste and beepollen-based beverage," Innovative Food Science and Emerging Technologies, vol. 37, pp. 10-17, 2016.

[118] B. Torres, B. K. Tiwari, A. Patras, P. J. Cullen, N. Brunton, and C. P. O'Donnell, "Stability of anthocyanins and ascorbic acid of high pressure processed blood orange juice during storage," Innovative Food Science and Emerging Technologies, vol. 12, no. 2, pp. 93-97, 2011.

[119] A. Morata, I. Loira, R. Vejarano et al., "Grape processing by high hydrostatic pressure: effect on microbial populations, phenol extraction and wine quality," Food and Bioprocess Technology, vol. 8, no. 2, pp. 277-286, 2015.

[120] K. Marszałek, Ł. Woźniak, B. Kruszewski, and S. Skąpska, "The effect of high pressure techniques on the stability of anthocyanins in fruit and vegetables," International Journal of Molecular Sciences, vol. 18, no. 2, p. 277, 2017.

[121] E. Betoret, N. Betoret, J. V. Carbonell, and P. Fito, "Effects of pressure homogenization on particle size and the functional properties of citrus juices," Journal of Food Engineering, vol. 92, no. 1, pp. 18-23, 2009.

[122] P. Maresca, F. Donsì, and G. Ferrari, "Application of a multipass high-pressure homogenization treatment for the pasteurization of fruit juices," Journal of Food Engineering, vol. 104, no. 3, pp. 364-372, 2011.

[123] J. Welti-Chanes, C. Ochoa-Velasco, and J. Guerrero-Beltrán, "High-pressure homogenization of orange juice to inactivate pectinmethylesterase," Innovative Food Science and Emerging Technologies, vol. 10, no. 4, pp. 457-462, 2009.

[124] P. Paquin, “Technological properties of high pressure homogenizers: the effect of fat globules, milk proteins, and polysaccharides," International Dairy Journal, vol. 9, no. 3-6, pp. 329-335, 1999.

[125] F. Donsì, L. Esposito, E. Lenza, B. Senatore, and G. Ferrari, "Production of shelf-stable annurca apple juice with pulp by high pressure homogenization," International Journal of Food Engineering, vol. 5, no. 4, 2009.

[126] N. Lacroix, I. Fliss, and J. Makhlouf, "Inactivation of pectin methylesterase and stabilization of opalescence in orange juice by dynamic high pressure," Food Research International, vol. 38, no. 5, pp. 569-576, 2005.

[127] F. Patrignani, L. Vannini, S. L. Sado Kamdem, R. Lanciotti, and M. E. Guerzoni, "Potentialities of high-pressure homogenization to inactivate Zygosaccharomyces bailii in fruit juices," Journal of Food Science, vol. 75, no. 2, pp. M116M120, 2010.

[128] F. Patrignani, L. Vannini, S. L. Sado Kamdem, R. Lanciotti, and M. Elisabetta Guerzoni, "Effect of high pressure homogenization on Saccharomyces cerevisiae inactivation and physico-chemical features in apricot and carrot juices," International Journal of Food Microbiology, vol. 136, no. 1, pp. 26-31, 2009.

[129] N. Toro-Funes, J. Bosch-Fusté, M. T. Veciana-Nogués, and M. C. Vidal-Carou, "Influence of ultra-high-pressure homogenization treatment on the phytosterols, tocopherols, and polyamines of almond beverage," Journal of Agricultural and Food Chemistry, vol. 62, no. 39, pp. 9539-9543, 2014.

[130] K. Briviba, V. Gräf, E. Walz, B. Guamis, and P. Butz, "Ultra high pressure homogenization of almond milk: Physicochemical and physiological effects," Food Chemistry, vol. 192, pp. 82-89, 2016.

[131] J. S. Won, M. H. Kim, G. J. Han, B. S. Noh, and S. C. Min, "Preservation of strawberry juice by dynamic high-pressure processing," Korean Journal of Food Science and Technology, vol. 47, no. 4, pp. 480-485, 2015.

[132] N. Toro-Funes, J. Bosch-Fusté, M. T. Veciana-Nogués, and M. C. Vidal-Carou, "Effect of ultra high pressure homogenization treatment on the bioactive compounds of soya milk," Food Chemistry, vol. 152, pp. 597-602, 2014.

[133] Á. Suárez-Jacobo, C. E. Rüfer, R. Gervilla, B. Guamis, A. X. Roig-Sagués, and J. Saldo, "Influence of ultra-high pressure homogenisation on antioxidant capacity, polyphenol and vitamin content of clear apple juice," Food Chemistry, vol. 127, no. 2, pp. 447-454, 2011.

[134] R. Velázquez-Estrada, M. M. Hernández-Herrero, C. E. Rüfer, B. Guamis-López, and A. X. Roig-Sagués, "Influence of ultra high pressure homogenization processing on bioactive compounds and antioxidant activity of orange juice," Innovative Food Science and Emerging Technologies, vol. 18, pp. 89-94, 2013.

[135] A. Panozzo, L. Lemmens, A. Van Loey, L. Manzocco, M. C. Nicoli, and M. Hendrickx, "Microstructure and bioaccessibility of different carotenoid species as affected by 
high pressure homogenisation: a case study on differently coloured tomatoes," Food Chemistry, vol. 141, no. 4, pp. 4094-4100, 2013.

[136] Z. He, Y. Tao, M. Zeng et al., "High pressure homogenization processing, thermal treatment and milk matrix affect in vitro bioaccessibility of phenolics in apple, grape and orange juice to different extents," Food Chemistry, vol. 200, pp. 107-116, 2016.

[137] Y. Yu, J. Wu, Y. Xu, G. Xiao, and B. Zou, "Effect of high pressure homogenization and dimethyl dicarbonate (DMDC) on microbial and physicochemical qualities of mulberry juice," Journal of Food Science, vol. 81, no. 3, pp. M702-M708, 2016.

[138] I. Odriozola-Serrano, R. Soliva-Fortuny, T. HernándezJover, and O. Martín-Belloso, "Carotenoid and phenolic profile of tomato juices processed by high intensity pulsed electric fields compared with conventional thermal treatments," Food Chemistry, vol. 112, no. 1, pp. 258-266, 2009.

[139] I. Odriozola-Serrano, R. Soliva-Fortuny, and O. MartínBelloso, "Impact of high-intensity pulsed electric fields variables on vitamin $\mathrm{C}$, anthocyanins and antioxidant capacity of strawberry juice," LWT-Food Science and Technology, vol. 42, no. 1, pp. 93-100, 2009.

[140] F. Donsì, G. Ferrari, and G. Pataro, "Applications of pulsed electric field treatments for the enhancement of mass transfer from vegetable tissue," Food Engineering Reviews, vol. 2, no. 2, pp. 109-130, 2010.

[141] C. Sánchez-Moreno, L. Plaza, P. Elez-Martínez, B. De Ancos, O. Martín-Belloso, and M. Pilar Cano, "Impact of high pressure and pulsed electric fields on bioactive compounds and antioxidant activity of orange juice in comparison with traditional thermal processing," Journal of Agricultural and Food Chemistry, vol. 53, no. 11, pp. 4403-4409, 2005.

[142] F. Barba, H. Jäger, N. Meneses, M. J. Esteve, A. Frígola, and D. Knorr, "Evaluation of quality changes of blueberry juice during refrigerated storage after high-pressure and pulsed electric fields processing," Innovative Food Science and Emerging Technologies, vol. 14, pp. 18-24, 2012.

[143] P. Elez-Martinez and O. Martin-Belloso, "Effects of high intensity pulsed electric field processing conditions on vitamin $\mathrm{C}$ and antioxidant capacity of orange juice and gazpacho, a cold vegetable soup," Food Chemistry, vol. 102, no. 1, pp. 201-209, 2007.

[144] G. Oms-Oliu, I. Odriozola-Serrano, R. Soliva-Fortuny, and O. Martín-Belloso, "Effects of high-intensity pulsed electric field processing conditions on lycopene, vitamin $\mathrm{C}$ and antioxidant capacity of watermelon juice," Food Chemistry, vol. 115, no. 4, pp. 1312-1319, 2009.

[145] Á. R. Marsellés-Fontanet, A. Puig-Pujol, P. Olmos, S. MínguezSanz, and O. Martín-Belloso, "A comparison of the effects of pulsed electric field and thermal treatments on grape juice," Food and Bioprocess Technology, vol. 6, no. 4, pp. 978-987, 2013.

[146] L. Plaza, C. Sánchez-Moreno, B. De Ancos, P. Elez-Martínez, O. Martín-Belloso, and M. Pilar Cano, "Carotenoid and flavanone content during refrigerated storage of orange juice processed by high-pressure, pulsed electric fields and low pasteurization," LWT-Food Science and Technology, vol. 44, no. 4, pp. 834-839, 2011.

[147] L. J. Quitão-Teixeira, I. Odriozola-Serrano, R. Soliva-Fortuny, A. Mota-Ramos, and O. Martín-Belloso, "Comparative study on antioxidant properties of carrot juice stabilised by highintensity pulsed electric fields or heat treatments," Journal of the Science of Food and Agriculture, vol. 89, no. 15, pp. 2636-2642, 2009.

[148] E. Agcam, A. Akyıld1z, and G. A. Evrendilek, "Comparison of phenolic compounds of orange juice processed by pulsed electric fields (PEF) and conventional thermal pasteurisation," Food Chemistry, vol. 143, pp. 354-361, 2014.

[149] L. Zhao, S. Zhang, H. Uluko et al., "Effect of ultrasound pretreatment on rennet-induced coagulation properties of goat's milk," Food Chemistry, vol. 165, pp. 167-174, 2014.

[150] Z. Liu, P. Juliano, R. P. W. Williams, J. Niere, and M. A. Augustin, "Ultrasound effects on the assembly of casein micelles in reconstituted skim milk," Journal of Dairy Research, vol. 81, no. 2, pp. 146-155, 2014.

[151] Z. Liu, P. Juliano, R. P. W. Williams, J. Niere, and M. A. Augustin, "Ultrasound improves the renneting properties of milk," Ultrasonics Sonochemistry, vol. 21, no. 6, pp. 2131-2137, 2014.

[152] P. Sfakianakis and C. Tzia, "Flavor and sensory characteristics of yogurt derived from milk treated by high intensity ultrasound," in Nutrition, Functional and Sensory Properties of Foods, pp. 92-97, RSC, Cambridge, UK, 2013.

[153] P. Sfakianakis, E. Topakas, and C. Tzia, "Comparative study on high-intensity ultrasound and pressure milk homogenization: effect on the kinetics of yogurt fermentation process," Food and Bioprocess Technology, vol. 8, no. 3, pp. 548-557, 2015.

[154] O. Gursoy, Y. Yilmaz, O. Gokce, and K. Ertan, "Effect of ultrasound power on physicochemical and rheological properties of yoghurt drink produced with thermosonicated milk," Emirates Journal of Food and Agriculture, vol. 28, no. 4, p. 235, 2016.

[155] S. H. Monteiro, E. K. Silvab, V. O. Alvarenga et al., "Effects of ultrasound energy density on the non-thermal pasteurization of chocolate milk beverage," Ultrasonics Sonochemistry, vol. 42, pp. 1-10, 2018.

[156] C. A. García-González, M. C. Camino-Rey, M. Alnaief, C. Zetzl, and I. Smirnovaa, "Supercritical drying of aerogels using $\mathrm{CO}_{2}$ : effect of extraction time on the end material textural properties," Journal of Supercritical Fluids, vol. 66, pp. 297-306, 2012.

[157] G. Ferrentino, S. Balzan, A. Dorigato, A. Pegoretti, and S. Spilimbergo, "Effect of supercritical carbon dioxide pasteurization on natural microbiota, texture, and microstructure of fresh-cut coconut," Journal of Food Science, vol. 77, no. 5, pp. E137-E143, 2012.

[158] G. Ferrentino, S. Balzan, and S. Spilimbergo, "Supercritical carbon dioxide processing of dry cured ham spiked with Listeria monocytogenes: inactivation kinetics, color, and sensory evaluations," Food and Bioprocess Technology, vol. 6, no. 5, pp. 1164-1174, 2013.

[159] S. Spilimbergo, D. Komes, A. Vojvodic, B. Levaj, and G. Ferrentino, "High pressure carbon dioxide pasteurization of fresh-cut carrot," Journal of Supercritical Fluids, vol. 79, pp. 92-100, 2013.

[160] V. Scholtz, J. Pazlarova, H. Souskova, J. Khun, and J. Julakd, "Nonthermal plasma-a tool for decontamination and disinfection," Biotechnology Advances, vol. 33, no. 6, pp. 1108-1119, 2015.

[161] D. Ziuzina, S. Patil, P. J. Cullen, K. M. Keener, and P. Bourke, "Atmospheric cold plasma inactivation of Escherichia coli in liquid media inside a sealed package," Journal of Applied Microbiology, vol. 114, no. 3, pp. 778-787, 2013.

[162] T. Vukusic, M. Shi, Z. Herceg, S. Rogers, P. Estifaee, and S. M. Thagard, "Liquid-phase electrical discharge plasmas 
with a silver electrode for inactivation of a pure culture of Escherichia coli in water," Innovative Food Science and Emerging Technologies, vol. 38, pp. 407-413, 2016.

[163] F. Grzegorzewski, J. Ehlbeck, O. Schlüter, L. W. Kroh, and S. Rohn, "Treating lamb's lettuce with a cold plasmainfluence of atmospheric pressure Ar plasma immanent species on the phenolic profile of Valerianella locusta," LWTFood Science and Technology, vol. 44, no. 10, pp. 2285-2289, 2011.

[164] N. N. Misra, S. K. Pankaj, J. M. Frias, K. M. Keener, and P. J. Cullen, "The effects of nonthermal plasma on chemical quality of strawberries," Postharvest Biology and Technology, vol. 110, pp. 197-202, 2015.

[165] Z. Herceg, D. B. Kovačević, J. G. Kljusurić, A. R. Jambrak, Z. Zorić, and V. Dragović-Uzelac, "Gas phase plasma impact on phenolic compounds in pomegranate juice," Food Chemistry, vol. 190, pp. 665-672, 2016.

[166] D. B. Kovačević, P. Putnik, V. Dragović-Uzelac, S. Pedisić, A. Režek Jambrak, and Z. Herceg, "Effects of cold atmospheric gas phase plasma on anthocyanins and color in pomegranate juice," Food Chemistry, vol. 190, pp. 317-323, 2016.

[167] I. E. Garofulić, A. R. Jambrak, S. Milošević, V. DragovićUzelac, Z. Zorić, and Z. Herceg, "The effect of gas phase plasma treatment on the anthocyanin and phenolic acid content of sour cherry Marasca (Prunus cerasus var Marasca) juice," LWT-Food Science and Technology, vol. 62, no. 1, pp. 894-900, 2015.

[168] K. Lukić, T. Vukušić, M. Tomašević, N. Ćurko, L. Gracin, and K. Kovačević Ganić, "The impact of high voltage electrical discharge plasma on the chromatic characteristics and phenolic composition of red and white wines," Innovative Food Science and Emerging Technologies, In press.

[169] R. Pereira and A. Vicente, "Environmental impact of novel thermal and non-thermal technologies in food processing," Food Research International, vol. 43, no. 7, pp. 1936-1943, 2010.

[170] A. Hospido, J. Davis, J. Berlin, and U. Sonesson, "A review of methodological issues affecting LCA of novel food products," International Journal of Life Cycle Assessment, vol. 15, no. 1, pp. 44-52, 2010.

[171] S. Toepfl, A. Mathys, V. Heinz, and D. Knorr, "Review: potential of high hydrostatic pressure and pulsed electric fields for energy efficient and environmentally friendly food processing," Food Reviews International, vol. 22, no. 4, pp. 405-423, 2006.

[172] ISO, ISO 14040:2006 Environmental Management-Life Cycle Assessment-Principles and Framework, International Organization for Standardization, Geneva, Switzerland, 2006.

[173] A. C. Hetherington, A. Li Borrion, O. Glyn Griffiths, and M. C. McManus, "Use of LCA as a development tool within early research: challenges and issues across different sectors," International Journal of Life Cycle Assessment, vol. 19, no. 1, pp. 130-143, 2014.

[174] G. Pardo and J. Zufía, "Life cycle assessment of foodpreservation technologies," Journal of Cleaner Production, vol. 28, pp. 198-207, 2012.

[175] L. Valsasina, M. Pizzol, S. Smetana, E. Georget, A. Mathys, and V. Heinz, "Life cycle assessment of emerging technologies: the case of milk ultra-high pressure homogenisation," Journal of Cleaner Production, vol. 142, pp. 2209-2217, 2017.

[176] K. Aganovic, S. Smetana, T. Grauwet et al., "Pilot scale thermal and alternative pasteurization of tomato and watermelon juice: an energy comparison and life cycle assessment," Journal of Cleaner Production, vol. 141, pp. 514$525,2017$. 


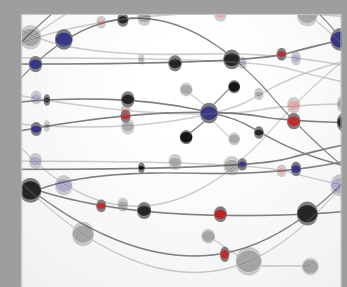

The Scientific World Journal
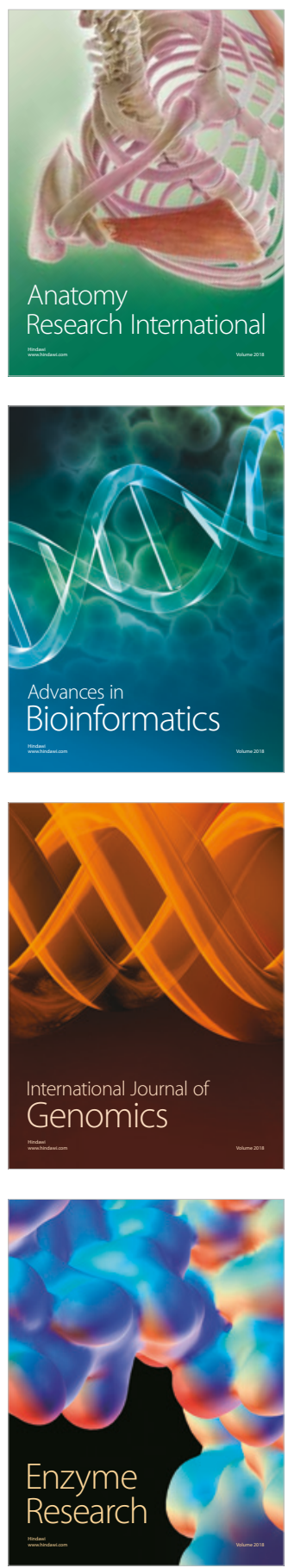
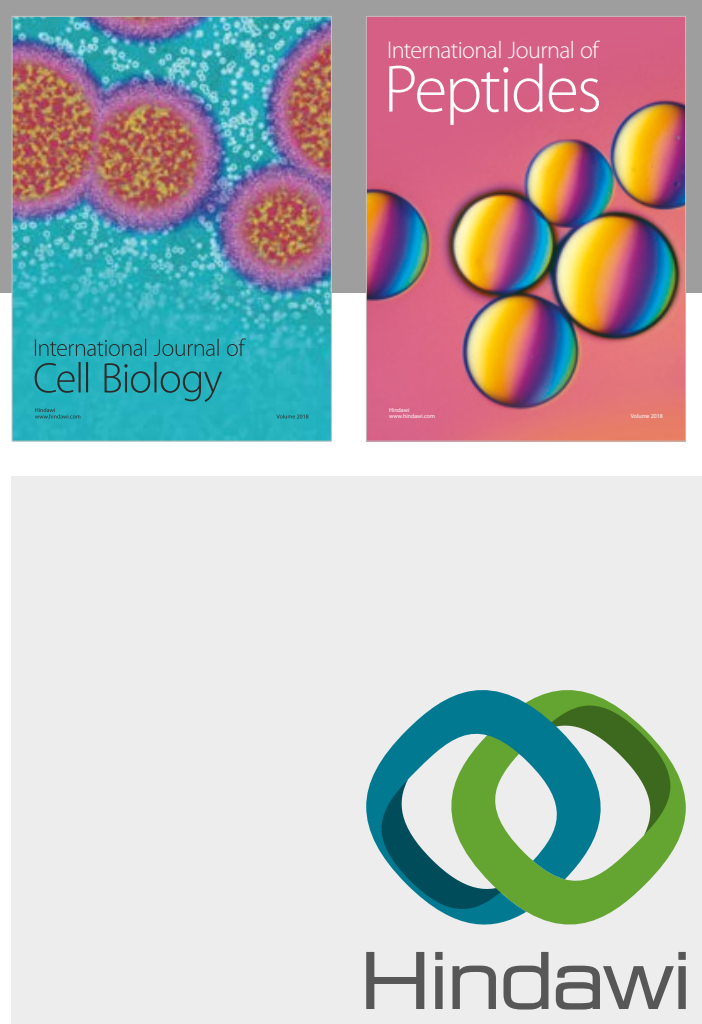

Submit your manuscripts at

www.hindawi.com
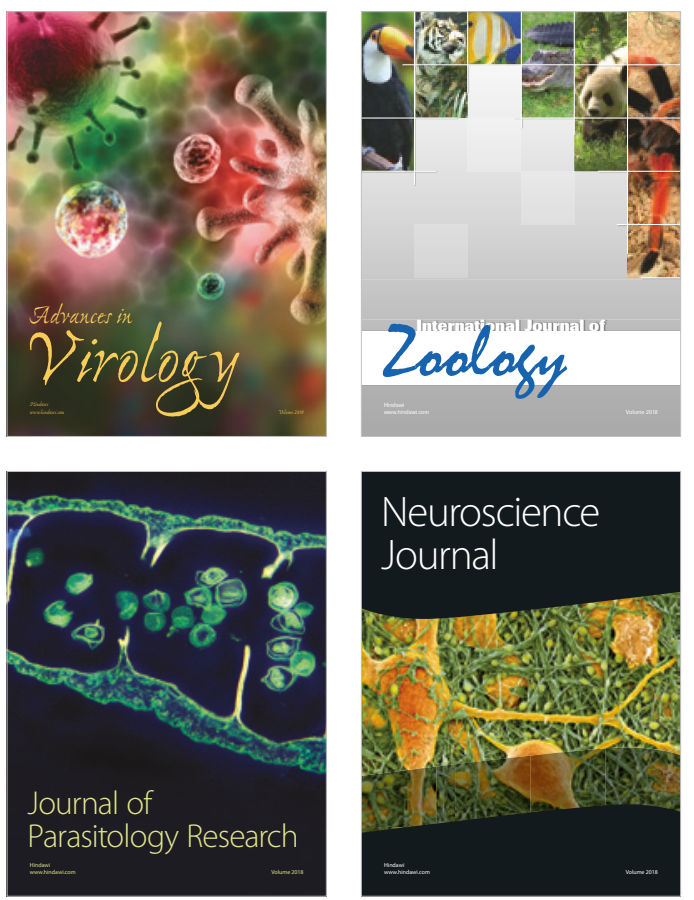
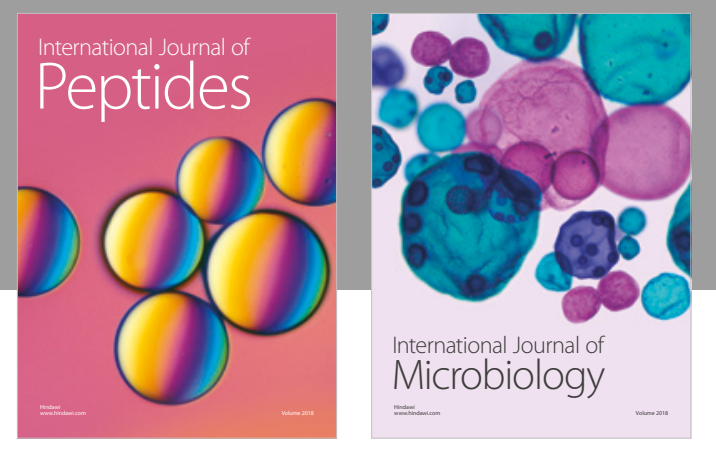

nternational Journal of Microbiology
Journal of
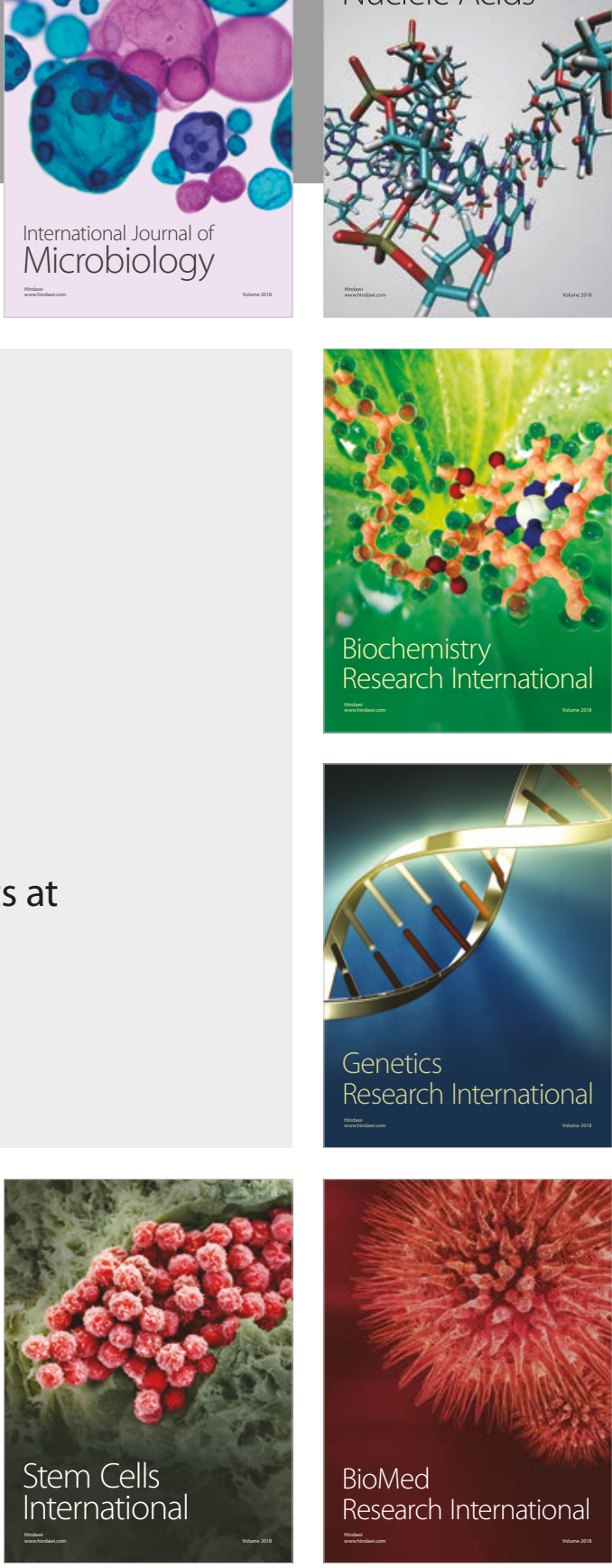
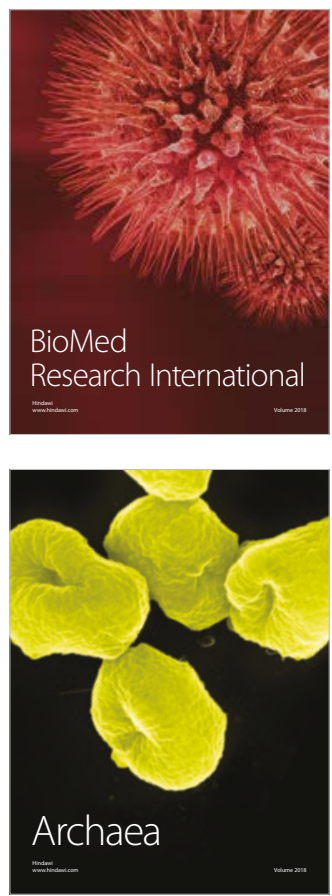